\title{
CEsifo \\ WORKING

\section{On the Effects of GATT/WTO Membership on Trade: They Are Positive and Large after All}

Mario Larch, José-Antonio Monteiro, Roberta Piermartini, Yoto V. Yotov 


\section{Impressum:}

CESifo Working Papers

ISSN 2364-1428 (electronic version)

Publisher and distributor: Munich Society for the Promotion of Economic Research - CESifo

$\mathrm{GmbH}$

The international platform of Ludwigs-Maximilians University's Center for Economic Studies and the ifo Institute

Poschingerstr. 5, 81679 Munich, Germany

Telephone +49 (0)89 2180-2740, Telefax +49 (0)89 2180-17845, email office@cesifo.de

Editor: Clemens Fuest

www.cesifo-group.org/wp

An electronic version of the paper may be downloaded

- from the SSRN website: www.SSRN.com

- from the RePEc website: www.RePEc.org

- from the CESifo website: www.CESifo-group.org/wp 


\title{
On the Effects of GATT/WTO Membership on Trade: They Are Positive and Large after All
}

\begin{abstract}
We capitalize on the latest developments in the empirical structural gravity literature to revisit the question of whether and how much does GATT/WTO membership affect international trade. We are the first to capture the non-discriminatory nature of GATT/WTO commitments by measuring the effects of GATT/WTO membership on international trade relative to domestic sales. These unilateral effects of GATT/WTO membership are found to be large, positive, and statistically significant. We also obtain bilateral GATT/WTO estimates, which are larger than those reported in the literature. In particular, our results imply that, on average, joining GATT and/or WTO has increased trade between members by $171 \%$ and trade between member and non-member countries by about $88 \%$. We also find that although both GATT/WTO has been effective in promoting trade between members, the WTO has been more effective in promoting trade with non-members than GATT. A battery of sensitivity experiments confirms the effectiveness of our methods and robustness of our main findings.
\end{abstract}

JEL-Codes: F130, F140, F160.

Keywords: GATT/WTO, international trade, domestic sales, structural gravity.

Mario Larch

Department of Law and Economics

University of Bayreuth / Germany

mario.larch@uni-bayreuth.de

Roberta Piermartini

Economic Research and Statistics Division

World Trade Organization / Switzerland

roberta.piermartini@wto.org
José-Antonio Monteiro

Economic Research and Statistics Division

World Trade Organization / Switzerland jose-antonio.monteiro@wto.org

Yoto V. Yotov

School of Economics

Drexel University / Philadelphia / USA

yotov@drexel.edu

May 28, 2019 


\section{Introduction}

What is the impact of the World Trade Organization (WTO) on world trade? The trade literature has so far looked at this question focussing on the impact of the membership of the General Agreement on Tariffs and Trade (GATT) and/or of the WTO on bilateral trade. WTO has been treated as any other regional trade agreement (RTA) where countries exchange preferential access.

Typically, the effect of WTO in a gravity model is captured by a dummy variable that is equal to one if both countries in a pair are WTO members. Like for any trade agreement the underlying assumptions are: (i) growth in trade volumes as a result of WTO accession is influenced by the depth of the acceding country's commitments; (ii) WTO membership diverts, if any, trade from other non-WTO member countries. Yet, the WTO agreements cover a number of areas such as technical regulations, standards, intellectual property and transparency requirements that apply behind the border. These measures are not bilateral and, therefore, cannot be capture by a dyadic WTO dummy.

Stimulated by the influential work of Rose (2004), in which he uses the canonical gravity model and finds no significant effect of WTO membership on bilateral trade and on diverting trade from non-members to members, several studies have re-assessed the impact of WTO membership by refining Rose's gravity specification across various dimensions. These studies have typically focused on three main issues: (i) the need to distinguish between asymmetries in commitments across membership, (ii) contemporaneous existence of other trade agreements, and (iii) the omission of zero trade observations.

Accounting for different levels of liberalization across WTO members, Subramanian and Wei (2007) argue that WTO does increase trade, but unevenly. GATT/WTO increase trade by $65 \%$ for developed countries, by 32\% for developing countries that acceded WTO after 1995 and has no impact on developing countries already members of the GATT. Accounting for pre-existing preferential trade relationships, Tomz et al. (2007) also show bilateral trade between two countries that are either GATT/WTO Member or equally liberalised non-WTO members is $45 \%$ higher than otherwise. By the same token, Eicher and Henn (2011) find that the effect of the WTO membership on trade is only positive before the formation of RTAs and among proximate developing countries.

Papers that attempt to account for missing trade flows also provide conflicting results. Helpman et al. (2004) document a significant effect of WTO membership on both the volume of bilateral trade and the probability that two countries trade. Using nonparametric methods, Chang and Lee (2011) find a large and positive trade-promoting effect of WTO membership (between $74 \%$ to $277 \%$ for countries both in GATT/WTO). Dutt et al. (2013) find that WTO membership increases the extensive margin of exports by $25 \%$, but a negative impact on the intensive margin. Roy (2011) finds no statistically effect of WTO mem- 
bership once country-time fixed effects are included in the gravity model. As noted by Cheong et al. (2014) the fragility of WTO effect estimates in the standard gravity model is mainly due to the multicollinearity between the multilateral resistance terms and the WTO membership variable.

A common feature of all existing gravity studies that quantify the effects of GATT/WTO is that by design, due to the fact that structural gravity estimations require the use of country-specific fixed effects on the importer and on the exporter side, they cannot identify the impact of any country-specific changes that occur in member countries after joining WTO. At the same time, such country-specific changes are an important objective and a common consequence of WTO membership. Increased transparency and decreased trade policy uncertainty (TPU) are two good examples.

Enhancing transparency regarding the trade policies applied by its members and creating a predictable environment is an important component of the economic value of WTO and a key difference between the WTO and the 300 or so RTAs currently in force. ${ }^{1}$ Transparency of trade regime is a key ingredient of trade costs. A firm that wants to export to a market needs to know about the rules and regulations in force and so does a firm that searches for an input supplier. Murky regulations and lack of information on rules and disciplines in place in a certain country may be an important obstacle to trade. All these benefits though occur at the country level and are non-discriminatory to member and non-member countries. Thus, WTO membership provides a country-specific public good. All countries, members and non-members, have access to the information reported in trade policy review reports or online data for each of the WTO member states. However, existing studies have not been able to capture such benefits due to the fact that all country-specific characteristics that affect bilateral trade have been absorbed by country-specific fixed effects.

In addition, most WTO member countries apply their most favoured nation (MFN) tariff rates to all countries, including non-WTO member countries. Thus, a key change occurring with becoming a WTO member is the reduction of uncertainty, once again, at the country-specific level. The case of China is a well-known example in case. China was granted MFN status by the U.S. in the 1980s. But this status was subject to annual renewal by the Congress. Had the MFN status been revoked, China would have faced much higher rates. China's WTO accession in December 2001 changed few applied U.S. trade policy barriers. But it secured China's pre-existing MFN status permanently and reduced trade policy uncertainty. Handley and Limao (2017) estimate that the reduction of trade policy uncertainty (TPU) alone explains $22 \%$ of Chinese export growth to the U.S. since accession. However, the potential positive effect on trade of GATT/WTO membership on trade between members as well as trade between member and non-member that emerge

\footnotetext{
${ }^{1}$ Using a calibrated general equilibrium model of international trade, Ossa (2014) estimates that the success of the WTO at preventing trade wars (where countries freely fix tariffs unilaterally to their national optimum) is worth up to $\$ 340$ billion per year.
} 
from the TPU reducing effect of GATT/WTO membership have so far been neglected in existing gravity estimations because the TPU effect is country-specific and structural gravity models use country-specific fixed effects. Our paper addresses these deficiencies.

Stimulated by the debate in the literature on whether and how much GATT/WTO promote bilateral trade and by the inability of existing studies to identify the country-specific benefits of GATT/WTO membership, we capitalize on the latest developments in the empirical structural gravity literature to re-evaluate the impact of GATT and WTO membership on international trade. The key adjustment that we propose to gravity estimations that evaluate the impact of GATT/WTO is to allow for possible trade diversion effects of GATT/WTO membership from domestic sales. This adjustment is consistent with gravity theory and also with the objectives of GATT and WTO. Our analysis demonstrates that not accounting for this channel may lead to severe biases in the estimates of the GATT/WTO effects and our methods enable us to make three contributions to the existing literature.

First, we obtain unilateral estimates of the effects of GATT/WTO membership. Specifically, our results imply that, on average, joining GATT or WTO has led to about $72 \%$ increase in the international trade of member countries relative to their domestic sales. This is a novel result that cannot be found in the existing literature. The reason is that all existing gravity estimations of the impact of GATT/WTO are based exclusively on samples that only include international trade flows. Therefore, these studies cannot identify any unilateral GATT/WTO effects in the presence of the exporter-time and importer-time fixed effects, which should be used in properly specified panel structural gravity estimations.

Second, within the same structural framework, we also re-evaluate the impact of GATT and WTO membership on bilateral trade between member countries. Our estimates are positive, statistically significant and larger as compared to corresponding estimates from the related literature. In particular, we find that GATT/WTO membership has led to about $171 \%$ increase in trade between member countries. This estimate is in the middle of the bounds, $74 \%$ to $277 \%$, of Chang and Lee (2011), to which we referred earlier. However, our estimate is significantly larger as compared to most other estimates from the literature. The explanation for this result is that our specification captures trade creation effects due to GATT/WTO membership and the reallocation of resources and production between international and domestic sales.

Finally, a by-product of our analysis is that the estimation specification that simultaneously includes the unilateral and the bilateral GATT/WTO variables enables us to also draw inference about the impact of GATT/WTO membership on trade between member and non-member countries. The estimates of these effects are also large, positive, and statistically significant. On average during the period of investigation and across the countries in our sample, GATT/WTO membership resulted in an increase of bilateral trade flows between member and non-member countries of about $88 \%$, revealing that GATT and WTO have promoted 
trade not only among members but between members and non-members too.

We conclude the main analysis by comparing the estimates that are obtained with the sample that includes consistently constructed intra-national trade flows to results based on a sample that only includes international trade flows. This experiment reveals that the GATT/WTO estimates that are obtained from the sample with international trade flows only are much smaller and, in fact, negative and marginally statistically significant. Therefore, we conclude that not allowing for possible diversion effects of WTO membership from internal trade may lead to severe biases in gravity estimations of the impact of GATT/WTO.

A battery of sensitivity experiments confirms the effectiveness of our methods and the robustness of our main findings, while also uncovering novel insights about the impact of GATT and WTO on international trade between member countries but also between members and non-member countries. For example, we find that GATT and WTO were both effective in promoting international trade, however, we document differential effects of the impact of GATT vs. WTO depending on whether trade is between members or between members and non-members. Specifically, we find that GATT has been more effective in promoting bilateral trade between members as compared to WTO, while WTO was more effective in promoting trade with non-members as compared to GATT. Thus, we conclude that GATT acted more like a RTA, while WTO has been much more effective in promoting members' overall trade and trade with non-members, i.e., in multilateral trade facilitation. In addition, the estimates from one of our experiments reveals that, while GATT/WTO promoted trade between all countries, the impact was stronger for trade among less developed nations than for trade between high and low income countries.

The rest of the paper is organized as follows. Section 2 presents our identification strategy within an empirical structural gravity model. Section 3 briefly describes our data. Section 4 presents and discusses our main findings. Section 5 offers results from a series of robustness checks and sensitivity experiments. Section 6 concludes.

\section{Identifying the Impact of GATT/WTO}

In order to study the effects of GATT/WTO membership on international trade, we capitalize on the latest developments in the empirical structural gravity literature, which are reflected in the following econometric 
model: ${ }^{2}$

$$
\begin{aligned}
X_{i j, t}= & \exp \left[\alpha_{0}+\alpha_{1} O N E_{-} G A T T W T O_{i j, t}+\alpha_{2} B O T H_{-} G A T T W T O_{i j, t}\right] \\
& \times \exp \left[\mu_{i j}+\pi_{i, t}+\chi_{j, t}+\mathbf{G R A V}_{\mathbf{i j}, \mathbf{t}} \psi\right]+\epsilon_{i j, t} .
\end{aligned}
$$

The dependent variable in equation (1), $X_{i j, t}$, denotes nominal trade flows from exporter $i$ to importer $j$ at time $t$. The panel dimension of $X_{i j, t}$ improves estimation efficiency and allows for a comprehensive treatment of all time-invariant bilateral trade costs with pair fixed effects, which we denote $\mu_{i j}{ }^{3} X_{i j, t}$ enters specification (1) in levels because, following Santos Silva and Tenreyro (2006; 2011), we will estimate (1) with the Poisson Pseudo Maximum Likelihood (PPML) estimator, which handles heteroskedasticity and, simultaneously, will enable us to include zero trade flows. Most important for our purposes, $X_{i j, t}$ includes intra-national trade flows in addition to international trade flows. The inclusion of intra-national trade flows is consistent with structural gravity theory, c.f., Yotov et al. (2016), ${ }^{4}$ and it has two important implications for our identification methods of the GATT/WTO effects, which we discuss sequentially and in detail next.

First, as demonstrated by Beverelli et al. (2018), the inclusion of intra-national trade flows allows for identification of the effects of unilateral and country-specific determinants of international trade, such as the unilateral effects of GATT/WTO membership. To that end, we define ONE_GATTWTO $O_{i j, t} \equiv$ $G A T T W T O_{i, t} \times B R D R_{i j}$, where $G A T T W T O_{i, t}$ is an indicator variable that takes a value of one if country $i$ is a GATT/WTO member at time $t$, and $B R D R_{i j}$ is a dummy variable that is equal to one for international trade and zero for internal trade. Thus, while GATT/WTO membership $\left(G A T T W T O_{i, t}\right)$ is indeed country-time specific and its impact cannot be identified in the presence of country-time fixed effects, the interaction $O N E_{-} G A T T W T O_{i j, t}$ is time-varying and bilateral by construction and, therefore, its effect can be identified even in the presence of exporter-time and importer-time fixed effects.

Second, as demonstrated by Dai et al. (2014), the use of intra-national trade flows in gravity estimations leads to improved estimates of the effects of bilateral trade policy variables. Specifically, Dai et al. (2014) demonstrate that the estimates of free trade agreements are biased downward in regressions that only rely on

\footnotetext{
${ }^{2}$ As is now well established, c.f., Arkolakis et al. (2012), the structural gravity model is representative of a very wide class of trade models. We refer the reader to Baldwin and Taglioni (2006), Anderson (2011), Costinot and Rodriguez-Clare (2014), Head and Mayer (2014), and Yotov et al. (2016) for surveys of the gravity literature.

${ }^{3}$ To obtain our main estimates, we follow the literature in using symmetric pair fixed effects. In the sensitivity analysis we demonstrate that the results are robust to the use of asymmetric pair fixed effects.

${ }^{4}$ One additional benefit of the inclusion of intra-national trade flows in gravity models is that it allows for identification of intra-national trade costs. Ramondo et al. (2016) demonstrate that the variation of internal trade costs helps resolve the puzzle in the open economy macro literature that larger countries should be richer than smaller countries. Agnosteva et al. (2014) offer methods that simultaneously obtain estimates of international, inter-provincial, and intra-provincial trade costs in Canada.
} 
international trade flows. The intuition is that these estimates cannot capture trade diversion effects from domestic sales. The same logic applies directly to our setting, where the estimate of the effect of the bilateral variable for GATT/WTO membership in specification (1), BOTH_GATTWTO ${ }_{i j, t}$, should be larger once the estimation sample includes intra-national trade flows. This is our second contribution to the existing literature, which estimates bilateral GATT/WTO membership effects exclusively based on samples that only include international trade flows.

The rest of the right-hand variables in specification (1) are standard in the gravity literature. $\pi_{i, t}$ and $\chi_{j, t}$ are exporter-time fixed effects and the importer-time fixed effects, respectively, which are included to control for the outward multilateral resistance terms and for the inward multilateral resistance terms of Anderson and van Wincoop (2003), which decompose the incidence of trade costs on the producers and on the consumers in each country, respectively. In addition, these fixed effects will control for all possible observable and unobservable country-specific determinants of trade and, therefore, they will mitigate further any endogeneity concerns related to GATT/WTO membership.

Finally, given that the pair fixed effects, $\mu_{i j}$, control for all time-invariant gravity variables, the vector $\mathbf{G R A V}_{\mathbf{i j}, \mathbf{t}}$ includes some remaining time-varying bilateral gravity covariates such as the presence of RTAs between countries $i$ and $j$ at time $t$ as well as a series of time-varying international border dummies, $\sum_{t} B R D R_{i j, t}$, which, following Bergstrand et al. (2015), will control for global trends in international trade.

\section{Data}

Following the recommendations of Glick and Rose (2016), we construct a new database that includes a very large number of countries. In addition, given the focus on the impact of GATT and WTO, we also aimed at a long time-period coverage. As a result, in order to perform the analysis, we constructed and employed an intra-national and international manufacturing trade dataset for 178 trading partners over the period 1980-2016. ${ }^{5}$ In addition to international and intra-national trade flows, we also employed data on WTO membership, RTAs, as well as a series of gravity variables, which are used standardly in the literature.

Intra-national trade flows, which are crucial for the implementation of our methods, are computed as the difference between gross output and exports. Gross manufacturing output is constructed using data from UN UNIDO INDSTAT 22017 and 2018 editions at the 2-digit level of International Standard Industrial Classification (ISIC) Revision 3, CEPII Trade, Production and Bilateral Protection Database (TradeProd) at the 3-digit level of ISIC Revision 2, World Bank's Trade, Production and Protection (TPP) database at the 3-digit level of ISIC Revision 2, and COMTRADE bilateral trade at the 3- and 2-digit level of ISIC

\footnotetext{
${ }^{5} \mathrm{~A}$ complete list of the countries in our sample is included in Table 3 reported in the Appendix.
} 
Revision 2. The UN UNIDO INDSTAT 2 is derived from INDSTAT3 ISIC Revision 2 and INDSTAT4 ISIC Revision 3. INDSTAT2 combines historical time series data starting 1963. The CEPII TradeProd and World Bank's TPP databases were used to provide production data for earlier years for some countries. ${ }^{6}$ Gross output data are available for 157 countries. However, due to data availability, the time coverage of gross output differs substantially across countries.

Data on bilateral trade are from UN Comtrade. Export flows, expressed in free on board (FOB), were complemented by mirrored import data flows after adjusting for cost, insurance and freight (CIF) costs. Estimates of bilateral CIF-FOB costs were obtained from OECD. Data on RTAs and GATT/WTO membership come from the WTO website. Data on bilateral distance, contiguous borders, colonial ties and common language were taken from CEPII. Further description on the variables in our sample, the data sources, and the dataset itself are available upon request.

\section{Estimation Results and Analysis}

Our main results, based on specification (1), appear in Table 1. All estimates are obtained in panel settings with the PPML estimator, and include exporter-time fixed effects, importer-time fixed effects, and countrypair fixed effects. The estimates of all fixed effects, including the constant term, are omitted from Table 1 for brevity. In addition, we also included a full set of time-varying border dummies for each year in our sample. However, for brevity, in Table 1 we only report border estimates every four years. The full set of time-varying border estimates can be found in Table 4 of the Appendix. Column (1) of Table 1 demonstrates that our specification allows for the identification of the unilateral effects of GATT/WTO membership, even in the presence of exporter-time and importer-time fixed effects.

Before we discuss the estimates of the unilateral GATT/WTO effects, we note that the rest of the estimates in column (1) are as expected. ${ }^{7}$ Specifically, the positive and statistically significant estimate on the covariate for RTAs implies that the adoption and implementation of RTAs promote bilateral international trade. The estimate on $R T A$ is smaller as compared to corresponding indexes from some related studies, e.g., Baier and Bergstrand (2007), but it is comparable to others, e.g., Baier et al. (2016). In addition,

\footnotetext{
${ }^{6}$ Given that the different databases are reported in different ISIC industry classifications, UNIDO INDSTAT data had to be translated from ISIC Revision 3 to ISIC Revision 2 using a correspondence table. However, ISIC Rev. 2 industry codes do not map one-to-one to the Rev. 3 industry codes. That is why country-specific concordance between ISIC Revision 3 to ISIC Revision 2 was constructed based on an iteration process for the matching years for which UNIDO INDSTAT data were available in both ISIC Revision 2 and ISIC Revision 3. The correlation between the original ISIC Revision 2 production values and the mapped values is larger than 0.99 for many countries.

${ }^{7}$ For benchmark gravity estimates, we refer the reader to Head and Mayer (2014), who obtain metaanalysis gravity indexes based on more than 150 studies, including more than 2500 gravity estimates.
} 
Table 1: Estimating The Effects of GATT/WTO

\begin{tabular}{|c|c|c|c|}
\hline & $\begin{array}{c}(1) \\
\text { Unilateral }\end{array}$ & $\begin{array}{c}(2) \\
\text { Unilateral\&Bilateral }\end{array}$ & $\begin{array}{c}(3) \\
\text { No Internal }\end{array}$ \\
\hline One_GATTWTO & $\begin{array}{c}0.544 \\
(0.094)^{* *}\end{array}$ & $\begin{array}{c}0.631 \\
(0.115)^{* *}\end{array}$ & \\
\hline Both_GATTWTO & & $\begin{array}{c}0.366 \\
(0.082)^{* *}\end{array}$ & $\begin{array}{l}-0.214 \\
(0.109)^{*}\end{array}$ \\
\hline RTA & $\begin{array}{c}0.135 \\
(0.051)^{* *}\end{array}$ & $\begin{array}{c}0.113 \\
(0.052)^{*}\end{array}$ & $\begin{array}{c}0.040 \\
(0.051)\end{array}$ \\
\hline INTL_BRDR_1980 & $\begin{array}{c}-1.164 \\
(0.065)^{* *}\end{array}$ & $\begin{array}{c}-1.124 \\
(0.070)^{* *}\end{array}$ & \\
\hline INTL_BRDR_1984 & $\begin{array}{c}-1.012 \\
(0.070)^{* *}\end{array}$ & $\begin{array}{l}-0.957 \\
(0.074)^{* *}\end{array}$ & \\
\hline INTL_BRDR_1988 & $\begin{array}{c}-0.878 \\
(0.067)^{* *}\end{array}$ & $\begin{array}{l}-0.844 \\
(0.071)^{* *}\end{array}$ & \\
\hline INTL_BRDR_1992 & $\begin{array}{c}-0.667 \\
(0.056)^{* *}\end{array}$ & $\begin{array}{l}-0.631 \\
(0.061)^{* *}\end{array}$ & \\
\hline INTL_BRDR_1996 & $\begin{array}{c}-0.496 \\
(0.060)^{* *}\end{array}$ & $\begin{array}{c}-0.459 \\
(0.067)^{* *}\end{array}$ & \\
\hline INTL_BRDR_2000 & $\begin{array}{c}-0.159 \\
(0.054)^{* *}\end{array}$ & $\begin{array}{c}-0.117 \\
(0.062)^{+}\end{array}$ & \\
\hline INTL_BRDR_2004 & $\begin{array}{l}-0.106 \\
(0.054)^{*}\end{array}$ & $\begin{array}{c}-0.097 \\
(0.056)^{+}\end{array}$ & \\
\hline INTL_BRDR_2008 & $\begin{array}{c}0.017 \\
(0.043)\end{array}$ & $\begin{array}{c}0.023 \\
(0.044)\end{array}$ & \\
\hline INTL_BRDR_2012 & $\begin{array}{c}0.049 \\
(0.024)^{*}\end{array}$ & $\begin{array}{c}0.051 \\
(0.025)^{*}\end{array}$ & \\
\hline Country pairs & 6347 & 6347 & 6286 \\
\hline Countries & 178 & 178 & 178 \\
\hline Intra-national trade & Yes & Yes & No \\
\hline Importer-time and Exporter-time fixed effects & Yes & Yes & Yes \\
\hline Symmetric country-pair fixed effects & Yes & Yes & Yes \\
\hline
\end{tabular}

Notes: This table reports estimation results from econometric models that study the impact of WTO on international trade. The dependent variable is bilateral trade in levels. All estimates are obtained in panel settings with the PPML estimator, exporter-time and importer-time fixed effects, time-varying border variables, as well as symmetric country-pair fixed effects. For presentation purposes, we omit the estimates of all fixed effects, including the constant, and we only report estimates of the time-varying international border dummies every four years. Standard errors are clustered by country pair and are reported in parentheses. ${ }^{+} p<0.10,{ }^{*} p<.05,{ }^{* *} p<.01$. See text for further details.

consistent with the estimates from Bergstrand et al. (2015), the decreasing estimates in absolute values of the border variables in column (1) capture the impact of globalization on international trade. To see this, we remind the reader that the average border effect in specification (1) is captured by the country-pair fixed effects. Thus, the estimates on the time-varying borders that we identify should be interpreted as deviations 
from the average border effect and, therefore, the positive time-varying border estimates that we obtain can be interpreted as decreasing border effects or, alternatively, as trade promoting globalization effects.

More importantly, turning to the estimate of the key variable of interest to us, we note two results. First, from a methodological perspective, we see from column (1) that, indeed, we can identify the impact of the unilateral effects of GATT/WTO membership, captured by ONE_GATTWTO ${ }_{i j, t}$, even in the presence of exporter-time and importer-time fixed effects. Second, we find that GATT/WTO membership has had a very strong positive impact on the trade of member countries. Specifically, our estimate implies that, on average, joining GATT or WTO has led to about $72 \%$ increase (calculated as $[\exp (0.544)-1] \times 100=72.29$ ) in the international trade of member countries relative to their domestic sales. This is a novel result that cannot be found in the existing literature, which relies exclusively on estimation samples that only included international trade flows and, therefore, cannot identify the unilateral GATT/WTO impact in the presence of the proper set of exporter-time and importer-time fixed effects in structural gravity estimations.

Next, we turn to the estimates from column (2) of Table 1, which capture our second contribution in relation to the existing literature. Here, in addition to the unilateral indicator variable for GATT/WTO membership from column (1), we also add a bilateral indicator, BOTH_GATTWTO ${ }_{i j, t}$, which takes a value of one if both countries are members of GATT/WTO, and it is equal to zero otherwise. Thus, by construction, the new BOTH_GATTWTO $O_{i j, t}$ covariate corresponds to the bilateral variables that are used standardly in the papers that study that effects of GATT and WTO, and to which we referred to in the introduction. We note that, since we do not change the definition of the unilateral covariate ONE_GATTWTO ${ }_{i j, t}$, then, by construction, the estimate on $B O T H_{-} G A T T W T O_{i j, t}$ should be interpreted as deviation from the corresponding estimate on $O N E \_G A T T W T O_{i j, t}$.

Three main results stand out from the estimates in column (2). First, the specification in column (2) allows for a simultaneous estimation of the unilateral and the bilateral effects of GATT/WTO membership on international trade. Second, in combination with the unilateral estimate, the estimate on BOTH_GATTWTO $O_{i j, t}$ suggests that the impact of WTO on trade between member countries is positive, large, and statistically significant. Specifically, we find that GATT/WTO membership has led to about $171 \%$ (calculated as $[\exp (0.997)-1] \times 100=171.01)$ increase in trade between member countries. In terms of magnitude, our estimate is in the middle of the bounds from Chang and Lee (2011), who obtain GATT/WTO effects between $74 \%$ to $277 \%$ for trade between member countries. However, our estimate is significantly larger as compared to most other estimates from the literature. The explanation for the larger GATT/WTO effect that we obtain is that our estimates captures diversions from domestic to international sales due to joining WTO. ${ }^{8}$ We find this intuitive for two related reasons: (ii) Domestic sales account for the largest

\footnotetext{
${ }^{8}$ This result is consistent with the findings of Dai et al. (2014), who obtain significantly larger estimates
} 
fraction of sales for most firms; and (ii) It is relatively easy to divert domestic sales to international sales.

The third main result from column (2) of Table 1 relates to trade between GATT/WTO member and non-member countries. To see it, note that by construction the remaining positive and significant estimate on ONE_GATTWTO $O_{i j, t}$ should be interpreted as the impact of GATT/WTO membership on international trade between member countries and non-member countries. Our results show that this estimate is large, positive and statistically significant. Specifically, we find that, on average during the period of investigation and across the countries in our sample, GATT/WTO membership resulted in an increase of bilateral trade flows between member and non-member countries of about $88 \%$ (calculated as $[\exp (0.631)-1] \times 100=87.95)$. The important implication is that GATT and WTO have promoted trade not only among members but between members and non-members too.

To emphasize our main contributions, we conclude the analysis in this section with a presentation of estimates that are obtained from the standard gravity specification that is employed in the rest of the related literature. Specifically, we obtain estimates from a sample that does not include intra-national trade, i.e., as all other studies, it only includes international trade flows. Our findings are presented in column (3) of Table 1, and three results deserve a discussion. First, we cannot obtain estimates of the impact of the unilateral GATT/WTO membership. The reason is that, when the sample includes only international trade flows, $O N E \_G A T T W T O_{i j, t}$ is perfectly collinear with the country-time fixed effects from the structural gravity estimations. Second, for the same reason, we cannot obtain estimates of the time-varying border variables. This explains the puzzle of Coe et al. (2002) who argue that gravity regressions cannot capture the impact of globalization. This puzzle is resolved by Bergstrand et al. (2015) with the use of intra-national trade flows.

Third, in relation to the estimates on the bilateral GATT/WTO membership variables that are employed standardly in the literature, we see from column (3) that the estimate on BOTH_GATTWTO ${ }_{i j, t}$ is actually negative (and marginally statistically significant). This result has two implications: (i) It is consistent with the wide range of estimates in the related literature; and (ii) It reinforces the argument that most of the trade creation effects of GATT/WTO come from diversion from domestic sales. ${ }^{9}$ Thus, we conclude that not allowing for possible diversion effects of WTO membership from internal trade may lead to severe biases in gravity estimations of the impact of GATT/WTO.

of the effects of RTAs once they allow for RTAs to divert sales from internal trade.

${ }^{9}$ Similarly, and consistent with the results from Dai et al. (2014), the estimate of the impact of RTAs is smaller in magnitude and it is not statistically significant. 


\section{$5 \quad$ Sensitivity Analysis and Additional Insights}

The purpose of this section is to confirm the effectiveness of our methods and to demonstrate the robustness of our main results to a battery of sensitivity experiments, which are motivated by developments in the structural gravity literature as well as by findings from the literature on the impact of GATT/WTO. Similar to the main analysis, all specifications in this section are obtained in panel settings that include exportertime fixed effects and importer-time fixed effects, whose estimates, including the constant term, are omitted for brevity. In addition, we also use a full set of time-varying border dummies for each year in the sample. However, for brevity, in Table 2 we only report border estimates every four years. The full set of time-varying border estimates can be found in Table 5 of Appendix A.2. To ease comparison with our main findings, in Column (1) of Table 2 we reproduce the main estimates from column (2) of Table 1.

We start by reproducing our main findings with the OLS estimator. OLS was the canonical gravity estimator for a long period of time, until the influential work of Santos Silva and Tenreyro (2006; 2011), who showed that OLS gravity estimates are not only biased but also inconsistent due heteroskedasticity of the trade data. The PPML estimator, on the other hand, is robust to heteroskedasticity. In addition, due to its multiplicative form, PPML also effectively takes into account the information contained in zero trade flows. The OLS estimates appear in column (2) of Table 2. Two main results stand out. First, we note that, despite being different in magnitude, the estimates of the effect of RTAs and the time-varying border dummies are comparable across the OLS and the PPML estimators. This result will remain valid across all specifications in Table 2. Therefore, we will not return to it again.

Second, and more important for our purposes, the estimates from column (2) of Table 2 demonstrate that we are able to identify simultaneously the unilateral and the bilateral impact of GATT/WTO with the OLS estimator. This is an important result as it validates our methods. This result will also remain valid across all specifications in Table 2 and, therefore, we will not return explicitly to it until the end of this section. Finally, we see from column (2) that while the estimates on both One_GATTWTO and Both_GATTWTO are positive, they are smaller in magnitude as compared to their PPML counterparts and they are not statistically significant. Following Santos Silva and Tenreyro (2006; 2011) we put our trust on the PPML estimates and we refer the reader to Larch et al. (2019) for further discussion on the drivers of the differences between PPML and OLS.

To obtain the results in column (3) of Table 2, we employ asymmetric country-pair fixed effects instead of the symmetric country-pair fixed effects that we used to obtain our main estimates. The motivation for the use of asymmetric pair fixed effects is that they will account for possible asymmetric bilateral trade costs between the countries in our sample. The main result from column (3) is that both the unilateral and 
the bilateral GATT/WTO estimates that are obtained with the asymmetric pair fixed effects are virtually identical to the main estimates from column (1) of Table 2. There are two possible explanations for the similarities between the two sets of results. First, this implies that bilateral trade costs are symmetric. Second, we note that the introduction of asymmetric pair fixed effects leads to multicollinearity issues with the country-specific fixed effects, suggesting that any asymmetries in trade costs are in fact country-specific rather than bilateral. In other words, our results imply that any asymmetries in the bilateral trade costs are in fact country-specific and, therefore, they have already been accounted for by the importer-time and exporter-time fixed effects, which are included in our specifications.

Table 2: Estimating The Effects of WTO - Robustness Analysis

\begin{tabular}{|c|c|c|c|c|c|c|c|}
\hline & $\begin{array}{c}(1) \\
\text { Main }\end{array}$ & $\begin{array}{c}(2) \\
\text { OLS }\end{array}$ & $\begin{array}{c}(3) \\
\text { AsymFE }\end{array}$ & $\begin{array}{c}(4) \\
\text { GATT/WTO }\end{array}$ & $\begin{array}{c}(5) \\
\text { CtryVar }\end{array}$ & $\begin{array}{c}(6) \\
\text { GravVar }\end{array}$ & $\begin{array}{c}(7) \\
\text { Poor/Rich }\end{array}$ \\
\hline One_GATTWTO & 0.631 & 0.220 & 0.631 & & 0.642 & 0.836 & \\
\hline Both_GATTWTO & $\begin{array}{c}(0.115)^{* *} \\
0.366 \\
(0.082)^{* *}\end{array}$ & $\begin{array}{c}(0.150) \\
0.124 \\
(0.140)\end{array}$ & $\begin{array}{c}(0.107)^{* *} \\
0.376 \\
(0.079)^{* *}\end{array}$ & & $\begin{array}{c}(0.133)^{* *} \\
0.350 \\
(0.070)^{* *}\end{array}$ & $\begin{array}{c}(0.232)^{* *} \\
1.007 \\
(0.160)^{* *}\end{array}$ & \\
\hline RTA & 0.113 & 0.217 & 0.116 & 0.120 & 0.066 & 0.428 & 0.108 \\
\hline One_GATT & & & & $\begin{array}{c}(0.051)^{*} \\
0.690 \\
(0.157)^{* *}\end{array}$ & & & \\
\hline One_WTO & & & & $\begin{array}{c}1.269 \\
(0.237)^{* *}\end{array}$ & & & \\
\hline Both_GATT & & & & $\begin{array}{c}0.531 \\
(0.113)^{* *}\end{array}$ & & & \\
\hline Both_WTO & & & & $\begin{array}{c}0.202 \\
(0.061)^{* *}\end{array}$ & & & \\
\hline POLITY_BRDR & & & & & $\begin{array}{c}0.021 \\
(0.011)^{+}\end{array}$ & & \\
\hline ln_GDP_BRDR & & & & & $\begin{array}{c}0.116 \\
(0.086)\end{array}$ & & \\
\hline ln_POP_BRDR & & & & & $\begin{array}{l}-0.078 \\
(0.352)\end{array}$ & & \\
\hline ln_DIST & & & & & & $\begin{array}{c}-0.613 \\
(0.062)^{* *}\end{array}$ & \\
\hline CNTG & & & & & & $\begin{array}{c}0.655 \\
(0.161)^{* *}\end{array}$ & \\
\hline LANG & & & & & & $\begin{array}{c}0.347 \\
(0.118)^{* *}\end{array}$ & \\
\hline CLNY & & & & & & $\begin{array}{c}0.162 \\
(0.097)^{+}\end{array}$ & \\
\hline One_GATTWTO_HH & & & & & & & $\begin{array}{c}0.346 \\
(0.305)\end{array}$ \\
\hline One_GATTWTO_HL & & & & & & & $\begin{array}{c}0.251 \\
(0.101)^{*}\end{array}$ \\
\hline One_GATTWTO_LL & & & & & & & $\begin{array}{c}0.742 \\
(0.127)^{* *} \\
\end{array}$ \\
\hline
\end{tabular}


Table 2 - Continued from previous page

\begin{tabular}{|c|c|c|c|c|c|c|c|}
\hline & $\begin{array}{c}(1) \\
\text { Main }\end{array}$ & $\begin{array}{c}(2) \\
\text { OLS }\end{array}$ & $\begin{array}{c}(3) \\
\text { AsymFE }\end{array}$ & $\begin{array}{c}(4) \\
\text { GATT/WTO }\end{array}$ & $\begin{array}{c}(5) \\
\text { CtryVar }\end{array}$ & $\begin{array}{c}(6) \\
\text { GravVar }\end{array}$ & $\begin{array}{c}(7) \\
\text { DevStat }\end{array}$ \\
\hline Both_GATTWTO_HH & & & & & & & $\begin{array}{l}-0.075 \\
(0.074)\end{array}$ \\
\hline Both_GATTWTO_HL & & & & & & & $\begin{array}{c}0.346 \\
(0.091)^{* *}\end{array}$ \\
\hline Both_GATTWTO_LL & & & & & & & $\begin{array}{c}0.674 \\
(0.069)^{* *}\end{array}$ \\
\hline INTL_BRDR_1980 & $\begin{array}{c}-1.124 \\
(0.070)^{* *}\end{array}$ & $\begin{array}{c}-1.368 \\
(0.241)^{* *}\end{array}$ & $\begin{array}{c}-1.126 \\
(0.070)^{* *}\end{array}$ & $\begin{array}{c}-0.866 \\
(0.269)^{* *}\end{array}$ & $\begin{array}{c}-0.926 \\
(0.174)^{* *}\end{array}$ & $\begin{array}{c}-5.427 \\
(0.361)^{* *}\end{array}$ & $\begin{array}{c}-1.133 \\
(0.070)^{* *}\end{array}$ \\
\hline INTL_BRDR_1984 & $\begin{array}{c}-0.957 \\
(0.074)^{* *}\end{array}$ & $\begin{array}{c}-1.358 \\
(0.204)^{* *}\end{array}$ & $\begin{array}{c}-0.959 \\
(0.073)^{* *}\end{array}$ & $\begin{array}{c}-0.692 \\
(0.268)^{*}\end{array}$ & $\begin{array}{c}-0.737 \\
(0.175)^{* *}\end{array}$ & $\begin{array}{c}-5.307 \\
(0.360)^{* *}\end{array}$ & $\begin{array}{c}-0.968 \\
(0.074)^{* *}\end{array}$ \\
\hline INTL_BRDR_1988 & $\begin{array}{c}-0.844 \\
(0.071)^{* *}\end{array}$ & $\begin{array}{c}-1.230 \\
(0.193)^{* *}\end{array}$ & $\begin{array}{c}-0.846 \\
(0.070)^{* *}\end{array}$ & $\begin{array}{c}-0.588 \\
(0.271)^{*}\end{array}$ & $\begin{array}{c}-0.688 \\
(0.141)^{* *}\end{array}$ & $\begin{array}{c}-5.220 \\
(0.366)^{* *}\end{array}$ & $\begin{array}{c}-0.844 \\
(0.071)^{* *}\end{array}$ \\
\hline INTL_BRDR_1992 & $\begin{array}{c}-0.631 \\
(0.061)^{* *}\end{array}$ & $\begin{array}{c}-0.866 \\
(0.160)^{* *}\end{array}$ & $\begin{array}{c}-0.633 \\
(0.060)^{* *}\end{array}$ & $\begin{array}{l}-0.375 \\
(0.272)\end{array}$ & $\begin{array}{c}-0.538 \\
(0.115)^{* *}\end{array}$ & $\begin{array}{c}-5.018 \\
(0.369)^{* *}\end{array}$ & $\begin{array}{c}-0.631 \\
(0.061)^{* *}\end{array}$ \\
\hline INTL_BRDR_1996 & $\begin{array}{c}-0.459 \\
(0.067)^{* *}\end{array}$ & $\begin{array}{c}-0.486 \\
(0.137)^{* *}\end{array}$ & $\begin{array}{c}-0.461 \\
(0.066)^{* *}\end{array}$ & $\begin{array}{c}-0.473 \\
(0.064)^{* *}\end{array}$ & $\begin{array}{c}-0.389 \\
(0.105)^{* *}\end{array}$ & $\begin{array}{c}-4.868 \\
(0.369)^{* *}\end{array}$ & $\begin{array}{c}-0.457 \\
(0.067)^{* *}\end{array}$ \\
\hline INTL_BRDR_2000 & $\begin{array}{c}-0.117 \\
(0.062)^{+}\end{array}$ & $\begin{array}{l}-0.183 \\
(0.131)\end{array}$ & $\begin{array}{c}-0.119 \\
(0.061)^{+}\end{array}$ & $\begin{array}{c}-0.133 \\
(0.058)^{*}\end{array}$ & $\begin{array}{l}-0.052 \\
(0.090)\end{array}$ & $\begin{array}{c}-4.531 \\
(0.368)^{* *}\end{array}$ & $\begin{array}{c}-0.117 \\
(0.062)^{+}\end{array}$ \\
\hline INTL_BRDR_2004 & $\begin{array}{c}-0.097 \\
(0.056)^{+}\end{array}$ & $\begin{array}{c}-0.084 \\
(0.123)\end{array}$ & $\begin{array}{c}-0.100 \\
(0.055)^{+}\end{array}$ & $\begin{array}{c}-0.100 \\
(0.055)^{+}\end{array}$ & $\begin{array}{c}-0.061 \\
(0.073)\end{array}$ & $\begin{array}{c}-4.620 \\
(0.368)^{* *}\end{array}$ & $\begin{array}{c}-0.097 \\
(0.056)^{+}\end{array}$ \\
\hline INTL_BRDR_2008 & $\begin{array}{c}0.023 \\
(0.044)\end{array}$ & $\begin{array}{c}0.003 \\
(0.116)\end{array}$ & $\begin{array}{c}0.022 \\
(0.044)\end{array}$ & $\begin{array}{c}0.022 \\
(0.044)\end{array}$ & $\begin{array}{c}0.024 \\
(0.057)\end{array}$ & $\begin{array}{c}-4.573 \\
(0.367)^{* *}\end{array}$ & $\begin{array}{c}0.023 \\
(0.044)\end{array}$ \\
\hline $\begin{array}{l}\text { INTL_BRDR_2012 } \\
\text { INTL_BRDR_2016 }\end{array}$ & $\begin{array}{c}0.051 \\
(0.025)^{*}\end{array}$ & $\begin{array}{c}0.104 \\
(0.094)\end{array}$ & $\begin{array}{c}0.050 \\
(0.024)^{*}\end{array}$ & $\begin{array}{c}0.050 \\
(0.025)^{*}\end{array}$ & $\begin{array}{c}0.040 \\
(0.032)\end{array}$ & $\begin{array}{c}-4.614 \\
(0.367)^{* *} \\
-4.722 \\
(0.367)^{* *}\end{array}$ & $\begin{array}{c}0.051 \\
(0.025)^{*}\end{array}$ \\
\hline Country pairs & 6347 & 6347 & 6347 & 6347 & 6167 & 6347 & 6347 \\
\hline Countries & 178 & 178 & 178 & 178 & 131 & 178 & 178 \\
\hline Estimator & PPML & OLS & PPML & PPML & PPML & PPML & PPML \\
\hline Imp-time Exp-time FEs & Yes & Yes & Yes & Yes & Yes & Yes & Yes \\
\hline Symmetric pair FEs & Yes & Yes & No & Yes & Yes & No & Yes \\
\hline Asymmetric pair FEs & No & No & Yes & No & No & No & No \\
\hline
\end{tabular}

Notes: This table reports robustness results from econometric models that study the impact of GATT/WTO on international trade. The dependent variable is bilateral trade in levels in all columns besides column (2), where the dependent variable is the log of bilateral trade flows. All estimates are obtained in panel settings with the PPML estimator besides column (2), where we use OLS, exporter-time and importer-time fixed effects, time-varying border variables, as well as symmetric (asymmetric in column (3)) country-pair fixed effects. For presentation purposes, we omit the estimates of all fixed effects, including the constant, and we only report estimates of the time-varying international border dummies every four years. Standard errors are clustered by country pair and are reported in parentheses. ${ }^{+} p<0.10,{ }^{*} p<.05,{ }^{* *} p<.01$. See text for further details.

In the next experiment we obtain separate estimates of the effects of GATT vs. WTO. Our findings are reported in column (4) of Table 2. The estimates on the bilateral variables (Both_GATT vs. Both_WTO) are both positive and statistically significant, suggesting that both GATT and WTO have promoted bilateral trade. Comparison between the estimates on the two variables reveals that GATT has been more effective in promoting bilateral trade between members as compared to WTO. Two possible explanations for this result 
include: (i) the fact that the founding members of the GATT were larger and more advanced economies and, therefore, the potential for trade promotion was larger; and (ii) that the initial trade base during the time of GATT was significantly smaller, leaving room for large relative increases. We also see from column (4) that the estimates on the unilateral variables (One_GATT vs. One_WTO) are also positive, large, and statistically significant. Furthermore, the estimates on One_GATT and One_WTO imply that WTO was more effective in promoting trade with non-members as compared to GATT. Thus, in combination, the results in column (4) imply that GATT and WTO were both effective in promoting international trade, however, GATT acted more like an RTA, while WTO membership has been much more effective in promoting members' overall trade and trade with non-members.

The implementation of our methods requires the introduction of intra-national trade flows in gravity estimations, which raises the question of potentially omitted country-specific covariates. Therefore, in the next experiment, we introduce three additional country-specific covariates that control for institutional quality $\left(P O L I T Y_{-} B R D R\right)$, development $\left(l_{n_{-}} G D P_{-} B R D R\right)$, and size $\left(l_{-} P O P_{-} B R D R\right)$, respectively. POLITY_BRDR is defined as the interaction between the index for institutional quality POLITY IV, which comes from the Center for Systemic Peace (CSP), and an indicator variable BRDR, which takes a value of one for international trade, and it is equal to zero otherwise. $l_{-} G D P_{-} B R D R$ is the interaction between the log of GDP and the border dummy $B R D R$. Finally, $l n_{-} P O P_{-} B R D R$ is the interaction between population and $B R D R$. Note that, in combination, $l_{-}{ }_{-} D P P_{-} B R D R$ and $l n_{-} P O P \_B R D R$ account for economic development. Data on GDP and population are from taken from the World Development Indicators.

The estimates from column (5) of Table 2 reveal that only one of the estimates on the three new countryspecific covariates is (marginally) statistically significant. Specifically, this is the estimate on the variable for institutional quality, POLITY_BRDR. More importantly for the current purposes, we see from column (5) that the estimates on the two GATT/WTO covariates are positive, large, and statistically significant. Furthermore, the estimates from column (5) are very similar in terms of magnitude to the main estimates in column (1).

In column (6) of Table 2 we replace the country-pair fixed effects with a set of standard gravity variables including the logarithm of bilateral distance $\left(l n_{-} D I S T\right)$ and three indicator variables that capture whether or not the countries share a common border $(C N T G)$, whether they share the same official language ( $L A N G)$, and whether they have ever been in a colonial relationship $(C L N Y)$. Data on bilateral distance, contiguous borders, common language, and colonial come from CEPII's distances database. The motivation for this experiment is that most of the existing gravity studies still rely on those standard time-invariant gravity variables, which are absorbed by the pair fixed effects in our main specification. 
Three results stand out from column (6). First, the estimates of the effects of the standard gravity covariates are all significant and have signs as expected. In terms of magnitude, they are readily comparable to the meta-analysis estimates of Head and Mayer (2014). This establishes the representatives of our sample. Second, we note that the time-varying border estimates are all negative, large, and statistically significant at any conventional level. As expected, this captures the presence of large international borders. Note that, when pair-fixed effects are not used in the estimation, we can identify the estimates of the border dummies for each year in our sample and they should be interpreted independently and not as deviations. The fact that the estimates on the time-varying border variables are decreasing in absolute values over time is consistent with our earlier findings and reflects the impact of globalization. Finally, and most important for our purposes, the estimates on the two WTO variables in column (6) are, once again, positive, statistically significant, and a bit larger as compared to their counterparts from our main specification in column (1).

The estimates in column (7) of Table 2 allow for differential GATT/WTO membership effects depending on whether countries are considered developed or developing (including least developed) countries. To perform this experiment, we split the countries in our sample according to World Bank country classification ${ }^{10}$ into two groups: developed $(\mathrm{H})$ and developing $(\mathrm{L})$ countries. ${ }^{11}$ We use these groups to split up each of the two key covariates, One_GATTWTO and Both_GATTWTO, into three different variables. With respect to One_GATTWTO: The first new variable is $\mathrm{One}_{-} G A T T W T O_{-} H \mathrm{H}$, and it is equal to one if both countries are developed countries and one of the countries is GATT/WTO member; The second new variable is One_GATTWTO_LL, and it is equal to one if both countries are developing countries and one of the countries is GATT/WTO member; Finally, the third new variable is One_GATTWTO_HL, and it is equal to one if one of the two countries is a developing country and one a developed country and one of the countries is GATT/WTO member. Similarly, we split Both_GATTWTO into three new variables, depending on their development status, but when both countries are GATT/WTO members. Thus, by construction, the first three new covariates, i.e., those based on One_GATTWTO will capture the heterogeneous effects of GATT/WTO on trade between members and non-members depending on their respective development status, while the second set of new covariates, i.e., those based on Both_GATTWTO will capture the heterogeneous effects of GATT/WTO on trade among members depending on their development status. Given that most developed countries were already GATT members at the beginning of the sample in 1980, the effect of GATT/WTO memberships of most developed countries is actually captured by their respective country pair fixed effects. In other words, the variables One_GATTWTO_HH and

\footnotetext{
${ }^{10}$ High-income countries are defined as developed countries, while middle- and low-income countries are defined as developing countries according to the World Bank's country classification.

${ }^{11}$ This classification is different from the one used in Subramanian and Wei (2007), where the group of 21 high-income countries, defined as industrialised countries, included only original or early GATT members.
} 
Both_GATTWTO_HH mainly capture the impact of GATT/WTO membership of developed countries who joined the GATT and/or WTO after 1980.

The results in column (7) of Table 2 reveal several interesting insights. The estimates on all three variables that are based on One_GATTWTO are positive, but the estimate of One_GATTWTO_HH is not statistically significant. Note that, given our set of fixed effects, the variable One_GATTWTO_HH only captures the effect of GATT/WTO membership of high-income countries that join GATT/WTO after 1980. Many of these high-income countries are specialized in natural resources extraction or services, which are not covered in our trade data and have more limited WTO commitments than high-income original founding GATT/WTO members. Therefore, the non-significant coefficient for One_GATTWTO_HH should not surprise and, most of all, should not be interpreted as saying that GATT/WTO membership did not increase trade among high-income countries. Column (6) of Table 2 appear to suggest that the effect of GATT/WTO on high income country is strong. In fact, in column (6), when we replace bilateral fixed effects with the traditional gravity bilateral variable, we estimate a larger effect of WTO membership (One_WTO). This larger coefficient partially captures the impact of WTO on trade between developed countries, which is in line with Subramanian and Wei (2007). Similarly, the impact of GATT/WTO on trade between members has been positive and significant when at least one of them was a developing country, and it has been especially strong when both trading partners were developing countries. The estimates of the variables capturing trade between GATT/WTO member countries paint a similar picture. In particular, the monotonically increasing and statistically significant estimates on Both_GATTWTO_HL and Both_GATTWTO_LL, respectively, suggest that GATT/WTO has been effective in promoting trade between members when one of them is a developing country and even more effective in promoting trade between members that are both developing countries.

Overall, we view the results from the sensitivity experiments that we performed and discussed in this section as supportive of our methods and main findings. The following three main conclusions remain valid. First, we can identify the unilateral effects of GATT and WTO. This result is valid across all robustness experiments. The single exception, where we obtained a positive effect, but which was not statistically significant, was with the OLS estimator. Second, we obtain estimates of the bilateral GATT/WTO effects for member countries that are larger than those from the existing literature. Finally, we find that GATT/WTO also promotes trade between member states and non-member countries. Once again, OLS is the single exception, where the estimate that we obtain is positive but not statistically significant. 


\section{Conclusions}

Our paper capitalizes on the latest developments in the empirical structural gravity literature to revisit the question of whether and how much GATT/WTO membership promotes international trade of member countries. The most significant departure from the existing literature is that our estimation of the structural gravity model includes intra-national trade in addition to international trade flows. This enabled us to make two contributions to the existing literature.

First, our framework enables us to identify for the first time in the literature the effects of GATT/WTO membership on international trade relative to domestic sales. Although these unilteral effects of GATT/WTO membership tend to be country- and time-specific, they are often large, positive and statistically significant at any conventional level. Specifically, our estimate implies that, on average, joining GATT and/or WTO has increased international trade of GATT/WTO member countries by about $72 \%$ relative to their domestic sales.

Second, the bilateral estimates of the effects of GATT/WTO membership on international trade between GATT/WTO member countries are positive, statistically significant and larger as compared to corresponding estimates from the related literature. In particular, our results imply that GATT/WTO membership has increased trade between members by $171 \%$ and trade between member countries and non-member countries by about $88 \%$. Part of this positive effect of GATT/WTO membership on trade between members as well as trade between member and non-member stems from the public good nature of GATT/WTO, namely the reduction in trade policy uncertainty associated with GATT/WTO membership, that gravity models have so far neglected.

A series of sensitivity experiments confirmed the effectiveness of our methods and the robustness of our main findings. In addition, we find that GATT has been more effective in promoting bilateral trade between members as compared to WTO, while WTO was more effective in promoting trade with non-members as compared to GATT. While GATT/WTO promoted trade between all countries, the impact was much stronger for developing economies. Overall, our analysis suggests that the estimates of the GATT/WTO effects may be severely biased if one does not allow for possible trade diversion effects of GATT/WTO membership from domestic sales. 


\section{References}

Agnosteva, Delina E., James E. Anderson, and Yoto V. Yotov, "Intra-national Trade Costs: Measurement and Aggregation," NBER Working Paper No. 19872, 2014.

Anderson, James E., "The Gravity Model," Annual Review of Economics, 2011, 3, 133-160.

- and Eric van Wincoop, "Gravity with Gravitas: A Solution to the Border Puzzle," American Economic Review, 2003, 93 (1), 170-192.

Arkolakis, Costas, Arnaud Costinot, and Andrés Rodriguez-Clare, "New Trade Models, Same Old Gains?," American Economic Review, 2012, 102 (1), 94-130.

Baier, Scott L. and Jeffrey H. Bergstrand, "Do Free Trade Agreements Actually Increase Members' International Trade?," Journal of International Economics, 2007, 71 (1), 72-95.

_, Yoto V. Yotov, and Thomas Zylkin, "On the Widely Differing Effects of Free Trade Agreements: Lessons from Twenty Years of Trade Integration," School of Economics Working Paper Series, 2016-15, 2016.

Baldwin, Richard E. and Daria Taglioni, "Gravity for Dummies and Dummies for Gravity Equations," NBER Working Paper No. 12516, 2006.

Bergstrand, Jeffrey H., Mario Larch, and Yoto V. Yotov, "Economic Integration Agreements, Border Effects, and Distance Elasticities in the Gravity Equation," European Economic Review, 2015, 78, 307-327.

Beverelli, Cosimo, Alexander Keck, Mario Larch, and Yoto V. Yotov, "Institutional Quality, Trade and Development: A Quantitative Analysis," CESifo Working Paper No. 6920, 2018.

Chang, Pao-Li and Myoung-Jae Lee, "The WTO Trade Effect," Journal of International Economics, 2011, 85 (1), 53-71.

Cheong, Juyoung, Do Won Kwak, and Kam Ki Tang, "The WTO Puzzle, Multilateral Resistance Terms and Multicollinearity," Applied Economics Letters, 2014, 21 (13), 928-933.

Coe, David T., Arvind Subramanian, Natalia T. Tamirisa, and Rikhil Bhavnani, "The Missing Globalization Puzzle," IMF Working Paper No. 171, 2002.

Costinot, Arnaud and Andrés Rodriguez-Clare, "Trade Theory with Numbers: Quantifying the Consequences of Globalization," Chapter 4 in the Handbook of International Economics Vol. 4, eds. Gita Gopinath, Elhanan Helpman, and Kenneth S. Rogoff, Elsevier Ltd., Oxford, 2014.

Dai, Mian, Yoto V. Yotov, and Thomas Zylkin, "On the Trade-Diversion Effects of Free Trade Agreements," Economics Letters, 2014, 122 (2), 321-325.

Dutt, Pushan, Ilian Mihov, and Timothy Van Zandt, "The Effect of WTO on the Extensive and the Intensive Margins of Trade," Journal of International Economics, 2013, 91 (2), 204-219.

Eicher, Theo and Christian Henn, "In Search of WTO Trade Effects: Preferential Trade Agreements Promote Trade Strongly, But Unevenly," Journal of International Economics, 2011, 83 (2), 137-153.

Glick, Reuven and Andrew K. Rose, "Currency Unions and Trade: A post-EMU Reassessment," European Economic Review, 2016, 87 (C), 78-91.

Handley, Kyle and Nuno Limao, "Policy Uncertainty, Trade and Welfare: Theory and Evidence for China and the U.S.," American Economic Review, 2017, $10^{\text {r }}$ (9), 2731-2783. 
Head, Keith and Thierry Mayer, "Gravity Equations: Workhorse, Toolkit, and Cookbook," Chapter 3 in the Handbook of International Economics Vol. 4, eds. Gita Gopinath, Elhanan Helpman, and Kenneth S. Rogoff, Elsevier Ltd., Oxford, 2014.

Helpman, Elhanan, Marc J. Melitz, and Stephen R. Yeaple, "Export versus FDI with Heterogenous Firms," American Economic Review, 2004, 94 (1), 300-316.

Larch, Mario, Joschka Wanner, Yoto Yotov, and Thomas Zylkin, "The Currency Union Effect: A PPML Re-assessment with High-Dimensional Fixed Effects," Technical Report 32019.

Ossa, Ralph, "Trade Wars and Trade Talks with Data," American Economic Review, 2014, 104 (12), 4104-46.

Ramondo, Natalia, Andrés Rodriguez-Clare, and Milagro Saborio-Rodriguez, "Trade, Domestic Frictions, and Scale Effects," American Economic Review, 2016, 106 (10), 3159-3184.

Rose, Andrew K., "Do We Really Know That the WTO Increases Trade?," American Economic Review, 2004, 94 (1), 98-114.

Roy, Jayjit, "Is the WTO Mystery Really Solved?," Economics Letters, 2011, 113 (2), 127-130.

Santos Silva, J.M.C. and Silvana Tenreyro, "Further Simulation Evidence on the Performance of the Poisson Pseudo-Maximum Likelihood Estimator," Economics Letters, 2011, 112 (2), 220-222.

Santos Silva, Joao M. C. and Silvana Tenreyro, "The Log of Gravity," Review of Economics and Statistics, 2006, 88 (4), 641-658.

Subramanian, Arvind and Shang-Jin Wei, "The WTO Promotes Trade, Strongly But Unevenly," Journal of International Economics, 2007, 72 (1), 151-175.

Tomz, Michael, Judith Goldstein, and Douglas Rivers, "Do We Really Know That the WTO Increases Trade? Comment," American Economic Review, 2007, 97 (5), 2005-2018.

Yotov, Yoto V., Roberta Piermartini, José-Antonio Monteiro, and Mario Larch, An Advanced Guide to Trade Policy Analysis: The Structural Gravity Model, Geneva: UNCTAD and WTO, 2016. 


\section{Appendix}

\section{A.1. A List of Countries in the Sample}

Table 3: Country list

\begin{tabular}{|c|c|c|}
\hline & International trade & Internal trade \\
\hline Afghanistan & $1980-2016$ & $2002-2015$ \\
\hline Albania & 1980-2016 & 1986-2016 \\
\hline Algeria & $1980-2016$ & $1980-2015$ \\
\hline Andorra & 1980-2016 & \\
\hline Angola & $1980-2016$ & 2014-2015 \\
\hline Antigua and Barbuda & $1980-2016$ & \\
\hline Argentina & $1980-2016$ & 1984-2002 \\
\hline Australia & $1980-2016$ & $1980-2016$ \\
\hline Austria & $1980-2016$ & $1980-2016$ \\
\hline Bahamas & 1980-2016 & 1981-1998 \\
\hline Bahrain & $1980-2016$ & $1992-2016$ \\
\hline Bangladesh & $1980-2016$ & $1980-2011$ \\
\hline Barbados & $1980-2016$ & $1980-1997$ \\
\hline Belgium-Luxembourg & $1980-2016$ & $1980-2016$ \\
\hline Belize & $1980-2016$ & 1989-1992 \\
\hline Benin & 1980-2016 & 1980-1981 \\
\hline Bermuda & 1980-2016 & $2006-2015$ \\
\hline Bhutan & $1980-2016$ & \\
\hline Bolivia (Plurinational State of) & $1980-2016$ & $1980-2012$ \\
\hline Brazil & $1980-2016$ & $1990-2016$ \\
\hline British Virgin Islands & $1980-2016$ & \\
\hline Brunei Darussalam & $1980-2016$ & $2010-2010$ \\
\hline Bulgaria & $1980-2016$ & $1980-2016$ \\
\hline Burkina Faso & $1980-2016$ & $1980-1983$ \\
\hline Burundi & 1980-2016 & $1980-2013$ \\
\hline Cabo Verde & $1980-2016$ & \\
\hline Cambodia & $1980-2016$ & $1993-2000$ \\
\hline Cameroon & $1980-2016$ & $1980-2008$ \\
\hline Canada & $1980-2016$ & $1980-2016$ \\
\hline Cayman Islands & $1980-2016$ & \\
\hline Central African Republic & $1980-2016$ & $1980-1993$ \\
\hline Chad & $1980-2016$ & \\
\hline Chile & $1980-2016$ & $1980-2016$ \\
\hline China & $1980-2016$ & $1980-2016$ \\
\hline China, Hong Kong Special Administrative Region & $1980-2016$ & $1980-2016$ \\
\hline China, Macao & $1980-2016$ & $1980-2015$ \\
\hline Christmas Island & $1980-2016$ & \\
\hline Cocos (Keeling) Islands & $1980-2016$ & \\
\hline Colombia & $1980-2016$ & $1980-2016$ \\
\hline Comoros & $1980-2016$ & \\
\hline Congo & $1980-2016$ & $1981-2008$ \\
\hline Cook Islands & $1980-2016$ & \\
\hline
\end{tabular}


Table 3 - Continued from previous page

\begin{tabular}{|c|c|c|}
\hline & International trade & Internal trade \\
\hline Costa Rica & $1980-2016$ & $1980-2016$ \\
\hline CÁŻte d'Ivoire & $1980-2016$ & 1980-1997 \\
\hline Cuba & $1980-2016$ & 1980-1989 \\
\hline Cyprus & $1980-2016$ & $1980-2016$ \\
\hline Democratic People's Republic of Korea & $1980-2016$ & \\
\hline Democratic Republic of the Congo & $1980-2016$ & \\
\hline Denmark & $1980-2016$ & $1980-2016$ \\
\hline Djibouti & $1980-2016$ & \\
\hline Dominica & $1980-2016$ & \\
\hline Dominican Republic & $1980-2016$ & 1980-1984 \\
\hline East Timor & $1980-2016$ & \\
\hline Ecuador & 1980-2016 & 1980-2016 \\
\hline Egypt & $1980-2016$ & $1980-2016$ \\
\hline El Salvador & $1980-2016$ & $1980-1998$ \\
\hline Equatorial Guinea & $1980-2016$ & \\
\hline Falkland Islands (Malvinas) & $1980-2016$ & \\
\hline Faroe Islands & $1980-2016$ & \\
\hline Fiji & $1980-2016$ & $1980-2015$ \\
\hline Finland & $1980-2016$ & $1980-2016$ \\
\hline France & $1980-2016$ & $1980-2016$ \\
\hline French Polynesia & $1980-2016$ & \\
\hline Gabon & $1980-2016$ & 1980-1995 \\
\hline Gambia & $1980-2016$ & $1980-2004$ \\
\hline Germany & $1980-2016$ & $1980-2016$ \\
\hline Ghana & $1980-2016$ & $1980-2003$ \\
\hline Gibraltar & $1980-2016$ & \\
\hline Greece & $1980-2016$ & $1980-2016$ \\
\hline Greenland & $1980-2016$ & \\
\hline Grenada & $1980-2016$ & \\
\hline Guatemala & $1980-2016$ & 1980-1998 \\
\hline Guinea & $1980-2016$ & \\
\hline Guinea-Bissau & $1980-2016$ & \\
\hline Guyana & $1980-2016$ & \\
\hline Haiti & $1980-2016$ & 1988-1997 \\
\hline Honduras & $1980-2016$ & 1981-1996 \\
\hline Hungary & $1980-2016$ & $1980-2016$ \\
\hline Iceland & $1980-2016$ & $1980-2016$ \\
\hline India & $1980-2016$ & $1980-2016$ \\
\hline Indonesia & $1980-2016$ & $1980-2016$ \\
\hline Iran (Islamic Republic of) & $1980-2016$ & $1980-2016$ \\
\hline Iraq & $1980-2016$ & $1984-2013$ \\
\hline Ireland & $1980-2016$ & $1980-2016$ \\
\hline Israel & $1980-2016$ & $1980-2016$ \\
\hline Italy & $1980-2016$ & $1980-2016$ \\
\hline Jamaica & $1980-2016$ & 1980-1992 \\
\hline Japan & $1980-2016$ & $1980-2016$ \\
\hline Jordan & $1980-2016$ & $1980-2016$ \\
\hline Kenya & $1980-2016$ & $1980-2016$ \\
\hline Kiribati & $1980-2016$ & \\
\hline
\end{tabular}


Table 3 - Continued from previous page

\begin{tabular}{|c|c|c|}
\hline & International trade & Internal trade \\
\hline Kuwait & $1980-2016$ & $1980-2016$ \\
\hline Lao People's Democratic Republic & $1980-2016$ & 1999-1999 \\
\hline Lebanon & $1980-2016$ & 1998-2007 \\
\hline Liberia & $1980-2016$ & 1984-1985 \\
\hline Libya & $1980-2016$ & $1980-1980$ \\
\hline Madagascar & $1980-2016$ & $1980-2006$ \\
\hline Malawi & $1980-2016$ & $1980-2012$ \\
\hline Malaysia & $1980-2016$ & $1980-2016$ \\
\hline Maldives & $1980-2016$ & $2013-2015$ \\
\hline Mali & $1980-2016$ & \\
\hline Malta & $1980-2016$ & $1980-2014$ \\
\hline Mauritania & $1980-2016$ & \\
\hline Mauritius & $1980-2016$ & $1980-2016$ \\
\hline Mexico & $1980-2016$ & 1984-2016 \\
\hline Mongolia & $1980-2016$ & $1990-2016$ \\
\hline Montserrat & $1980-2016$ & \\
\hline Morocco & $1980-2016$ & $1980-2015$ \\
\hline Mozambique & $1980-2016$ & $1986-1998$ \\
\hline Myanmar & $1980-2016$ & $1989-2013$ \\
\hline Nauru & $1980-2016$ & \\
\hline Nepal & $1980-2016$ & $1986-2011$ \\
\hline Netherlands & $1980-2016$ & $1980-2016$ \\
\hline Netherlands Antilles & $1980-2010$ & \\
\hline New Caledonia & $1980-2016$ & \\
\hline New Zealand & $1980-2016$ & $1980-2016$ \\
\hline Nicaragua & $1980-2016$ & $1980-1985$ \\
\hline Niger & $1980-2016$ & $1990-2015$ \\
\hline Nigeria & $1980-2016$ & $1980-2004$ \\
\hline Niue & $1980-2016$ & \\
\hline Norfolk Island & $1982-2016$ & \\
\hline Norway & $1980-2016$ & $1980-2016$ \\
\hline Oman & $1980-2016$ & $1993-2016$ \\
\hline Pakistan & 1980-2016 & $1980-2006$ \\
\hline Panama & $1980-2016$ & $1980-2016$ \\
\hline Papua New Guinea & $1980-2016$ & 1980-2001 \\
\hline Paraguay & $1980-2016$ & $2001-2010$ \\
\hline Peru & $1980-2016$ & $1980-2016$ \\
\hline Philippines & $1980-2016$ & $1980-2016$ \\
\hline Poland & $1980-2016$ & $1982-2016$ \\
\hline Portugal & $1980-2016$ & $1980-2016$ \\
\hline Qatar & $1980-2016$ & $1987-2016$ \\
\hline Republic of Korea & $1980-2016$ & $1980-2016$ \\
\hline Romania & $1980-2016$ & $1985-2016$ \\
\hline Rwanda & $1980-2016$ & 1999-1999 \\
\hline Saint Helena & $1980-2016$ & \\
\hline Saint Kitts and Nevis & $1981-2016$ & \\
\hline Saint Lucia & $1980-2016$ & 1993-1997 \\
\hline Saint Pierre and Miquelon & $1980-2016$ & \\
\hline Saint Vincent and the Grenadines & $1980-2016$ & \\
\hline
\end{tabular}


Table 3 - Continued from previous page

\begin{tabular}{|c|c|c|}
\hline & International trade & Internal trade \\
\hline Samoa & $1980-2016$ & \\
\hline Sao Tome and Principe & $1980-2016$ & \\
\hline Saudi Arabia & $1980-2016$ & $1989-2016$ \\
\hline Senegal & 1980-2016 & 1980-2014 \\
\hline Seychelles & $1980-2016$ & \\
\hline Sierra Leone & $1980-2016$ & \\
\hline Singapore & 1980-2016 & 1980-2016 \\
\hline Solomon Islands & $1980-2016$ & \\
\hline Somalia & $1980-2016$ & 1986-1986 \\
\hline South Africa & $1980-2016$ & $1980-2016$ \\
\hline Spain & 1980-2016 & $1980-2016$ \\
\hline Sri Lanka & $1980-2016$ & $1980-2016$ \\
\hline Sudan & $1980-2011$ & $2001-2001$ \\
\hline Suriname & $1980-2016$ & 1980-1993 \\
\hline Sweden & $1980-2016$ & $1980-2016$ \\
\hline Switzerland & $1980-2016$ & $1986-2016$ \\
\hline Syrian Arab Republic & $1980-2016$ & $1980-2005$ \\
\hline Thailand & $1980-2016$ & $1982-2013$ \\
\hline Togo & $1980-2016$ & \\
\hline Tonga & $1980-2016$ & $1980-2004$ \\
\hline Trinidad and Tobago & $1980-2016$ & $1981-2006$ \\
\hline Tunisia & $1980-2016$ & $1980-2015$ \\
\hline Turkey & $1980-2016$ & $1980-2016$ \\
\hline Turks and Caicos Islands & $1980-2016$ & \\
\hline Uganda & $1980-2016$ & 1989-1989 \\
\hline United Arab Emirates & $1980-2016$ & $1981-2015$ \\
\hline United Kingdom of Great Britain and Northern Ireland & $1980-2016$ & $1980-2015$ \\
\hline United Republic of Tanzania & $1980-2016$ & $1980-2015$ \\
\hline United States of America & $1980-2016$ & $1980-2016$ \\
\hline Uruguay & $1980-2016$ & $1980-2014$ \\
\hline Vanuatu & $1980-2016$ & \\
\hline Venezuela (Bolivarian Republic of) & $1980-2016$ & $1980-1998$ \\
\hline Viet Nam & $1980-2016$ & $1998-2015$ \\
\hline Wallis and Futuna Islands & $1981-2016$ & \\
\hline Western Sahara & $1980-2016$ & \\
\hline Yemen & $1980-2016$ & $1988-2014$ \\
\hline Zambia & $1980-2016$ & $1980-1994$ \\
\hline Zimbabwe & $1980-2016$ & $2009-2015$ \\
\hline
\end{tabular}

Note: Unbalanced panel with internal trade data not necessarily available for every year. 


\section{A.2. Additional Estimation Results}

Table 4: Estimating The Effects of WTO

\begin{tabular}{|c|c|c|c|}
\hline & $\begin{array}{c}(1) \\
\text { Unilateral }\end{array}$ & $\begin{array}{c}(2) \\
\text { Unilateral\&Bilateral }\end{array}$ & $\begin{array}{c}(3) \\
\text { No Internal }\end{array}$ \\
\hline One_GATTWTO & $\begin{array}{c}0.544 \\
(0.094)^{* *}\end{array}$ & $\begin{array}{c}0.631 \\
(0.115)^{* *}\end{array}$ & \\
\hline Both_GATTWTO & & $\begin{array}{c}0.366 \\
(0.082)^{* *}\end{array}$ & $\begin{array}{l}-0.214 \\
(0.109)^{*}\end{array}$ \\
\hline RTA & $\begin{array}{c}0.135 \\
(0.051)^{* *}\end{array}$ & $\begin{array}{c}0.113 \\
(0.052)^{*}\end{array}$ & $\begin{array}{c}0.040 \\
(0.051)\end{array}$ \\
\hline INTL_BRDR_1980 & $\begin{array}{c}-1.164 \\
(0.065)^{* *}\end{array}$ & $\begin{array}{c}-1.124 \\
(0.070)^{* *}\end{array}$ & \\
\hline INTL_BRDR_1981 & $\begin{array}{c}-1.134 \\
(0.065)^{* *}\end{array}$ & $\begin{array}{c}-1.092 \\
(0.070)^{* *}\end{array}$ & \\
\hline INTL_BRDR_1982 & $\begin{array}{c}-1.135 \\
(0.067)^{* *}\end{array}$ & $\begin{array}{c}-1.095 \\
(0.072)^{* *}\end{array}$ & \\
\hline INTL_BRDR_1983 & $\begin{array}{l}-1.097 \\
(0.066)^{* *}\end{array}$ & $\begin{array}{c}-1.055 \\
(0.071)^{* *}\end{array}$ & \\
\hline INTL_BRDR_1984 & $\begin{array}{l}-1.012 \\
(0.070)^{* *}\end{array}$ & $\begin{array}{c}-0.957 \\
(0.074)^{* *}\end{array}$ & \\
\hline INTL_BRDR_1985 & $\begin{array}{c}-0.991 \\
(0.072)^{* *}\end{array}$ & $\begin{array}{c}-0.936 \\
(0.076)^{* *}\end{array}$ & \\
\hline INTL_BRDR_1986 & $\begin{array}{c}-0.986 \\
(0.067)^{* *}\end{array}$ & $\begin{array}{c}-0.954 \\
(0.071)^{* *}\end{array}$ & \\
\hline INTL_BRDR_1987 & $\begin{array}{c}-0.965 \\
(0.067)^{* *}\end{array}$ & $\begin{array}{c}-0.933 \\
(0.071)^{* *}\end{array}$ & \\
\hline INTL_BRDR_1988 & $\begin{array}{c}-0.878 \\
(0.067)^{* *}\end{array}$ & $\begin{array}{c}-0.844 \\
(0.071)^{* *}\end{array}$ & \\
\hline INTL_BRDR_1989 & $\begin{array}{c}-0.831 \\
(0.070)^{* *}\end{array}$ & $\begin{array}{c}-0.794 \\
(0.075)^{* *}\end{array}$ & \\
\hline INTL_BRDR_1990 & $\begin{array}{c}-0.687 \\
(0.060)^{* *}\end{array}$ & $\begin{array}{c}-0.653 \\
(0.064)^{* *}\end{array}$ & \\
\hline INTL_BRDR_1991 & $\begin{array}{c}-0.686 \\
(0.060)^{* *}\end{array}$ & $\begin{array}{c}-0.653 \\
(0.064)^{* *}\end{array}$ & \\
\hline INTL_BRDR_1992 & $\begin{array}{c}-0.667 \\
(0.056)^{* *}\end{array}$ & $\begin{array}{c}-0.631 \\
(0.061)^{* *}\end{array}$ & \\
\hline INTL_BRDR_1993 & $\begin{array}{l}-0.627 \\
(0.058)^{* *}\end{array}$ & $\begin{array}{l}-0.587 \\
(0.064)^{* *}\end{array}$ & \\
\hline INTL_BRDR_1994 & $\begin{array}{c}-0.539 \\
(0.059)^{* *}\end{array}$ & $\begin{array}{c}-0.501 \\
(0.065)^{* *}\end{array}$ & \\
\hline INTL_BRDR_1995 & $\begin{array}{c}-0.516 \\
(0.061)^{* *}\end{array}$ & $\begin{array}{c}-0.479 \\
(0.068)^{* *}\end{array}$ & \\
\hline INTL_BRDR_1996 & $\begin{array}{c}-0.496 \\
(0.060)^{* *}\end{array}$ & $\begin{array}{c}-0.459 \\
(0.067)^{* *}\end{array}$ & \\
\hline INTL_BRDR_1997 & $\begin{array}{l}-0.380 \\
(0.057)^{* *}\end{array}$ & $\begin{array}{c}-0.341 \\
(0.064)^{* *}\end{array}$ & \\
\hline INTL_BRDR_1998 & $\begin{array}{c}-0.312 \\
(0.052)^{* *}\end{array}$ & $\begin{array}{c}-0.273 \\
(0.060)^{* *}\end{array}$ & \\
\hline INTL_BRDR_1999 & $\begin{array}{l}-0.316 \\
(0.055)^{* *}\end{array}$ & $\begin{array}{c}-0.278 \\
(0.062)^{* *}\end{array}$ & \\
\hline
\end{tabular}


Table 4 - Continued from previous page

\begin{tabular}{|c|c|c|c|}
\hline & $\begin{array}{c}\text { (1) } \\
\text { Unilateral }\end{array}$ & $\begin{array}{c}(2) \\
\text { Unilateral\&Bilateral }\end{array}$ & $\begin{array}{c}(3) \\
\text { No Internal }\end{array}$ \\
\hline INTL_BRDR_2000 & $\begin{array}{c}-0.159 \\
(0.054)^{* *}\end{array}$ & $\begin{array}{c}-0.117 \\
(0.062)^{+}\end{array}$ & \\
\hline INTL_BRDR_2001 & $\begin{array}{c}-0.147 \\
(0.050)^{* *}\end{array}$ & $\begin{array}{c}-0.138 \\
(0.051)^{* *}\end{array}$ & \\
\hline INTL_BRDR_2002 & $\begin{array}{c}-0.138 \\
(0.054)^{* *}\end{array}$ & $\begin{array}{l}-0.129 \\
(0.055)^{*}\end{array}$ & \\
\hline INTL_BRDR_2003 & $\begin{array}{c}-0.167 \\
(0.058)^{* *}\end{array}$ & $\begin{array}{c}-0.158 \\
(0.060)^{* *}\end{array}$ & \\
\hline INTL_BRDR_2004 & $\begin{array}{l}-0.106 \\
(0.054)^{*}\end{array}$ & $\begin{array}{c}-0.097 \\
(0.056)^{+}\end{array}$ & \\
\hline INTL_BRDR_2005 & $\begin{array}{l}-0.075 \\
(0.051)\end{array}$ & $\begin{array}{l}-0.066 \\
(0.053)\end{array}$ & \\
\hline INTL_BRDR_2006 & $\begin{array}{l}-0.006 \\
(0.049)\end{array}$ & $\begin{array}{c}0.002 \\
(0.050)\end{array}$ & \\
\hline INTL_BRDR_2007 & $\begin{array}{l}-0.013 \\
(0.051)\end{array}$ & $\begin{array}{l}-0.006 \\
(0.053)\end{array}$ & \\
\hline INTL_BRDR_2008 & $\begin{array}{c}0.017 \\
(0.043)\end{array}$ & $\begin{array}{c}0.023 \\
(0.044)\end{array}$ & \\
\hline INTL_BRDR_2009 & $\begin{array}{l}-0.056 \\
(0.036)\end{array}$ & $\begin{array}{l}-0.052 \\
(0.037)\end{array}$ & \\
\hline INTL_BRDR_2010 & $\begin{array}{c}0.018 \\
(0.034)\end{array}$ & $\begin{array}{c}0.022 \\
(0.035)\end{array}$ & \\
\hline INTL_BRDR_2011 & $\begin{array}{c}0.057 \\
(0.031)^{+}\end{array}$ & $\begin{array}{c}0.060 \\
(0.032)^{+}\end{array}$ & \\
\hline INTL_BRDR_2012 & $\begin{array}{c}0.049 \\
(0.024)^{*}\end{array}$ & $\begin{array}{c}0.051 \\
(0.025)^{*}\end{array}$ & \\
\hline INTL_BRDR_2013 & $\begin{array}{c}0.066 \\
(0.024)^{* *}\end{array}$ & $\begin{array}{c}0.068 \\
(0.024)^{* *}\end{array}$ & \\
\hline INTL_BRDR_2014 & $\begin{array}{c}0.072 \\
(0.020)^{* *}\end{array}$ & $\begin{array}{c}0.073 \\
(0.020)^{* *}\end{array}$ & \\
\hline INTL_BRDR_2015 & $\begin{array}{c}0.097 \\
(0.015)^{* *}\end{array}$ & $\begin{array}{c}0.098 \\
(0.015)^{* *}\end{array}$ & \\
\hline Country pairs & 6347 & 6347 & 6286 \\
\hline Countries & 178 & 178 & 178 \\
\hline Intra-national trade & Yes & Yes & No \\
\hline Importer-time and Exporter-time fixed effects & Yes & Yes & Yes \\
\hline Symmetric country-pair fixed effects & Yes & Yes & Yes \\
\hline
\end{tabular}

Notes: This table is the complete version of Table 1 from the main text. The table reports estimation results from econometric models that study the impact of WTO on international trade. The dependent variable is bilateral trade in levels. All estimates are obtained in panel settings with the PPML estimator, exporter-time and importer-time fixed effects, as well as symmetric country-pair fixed effects. For presentation purposes, we omit the estimates of all fixed effects, including the constant. Standard errors are clustered by country pair and are reported in parentheses. ${ }^{+} p<0.10,{ }^{*} p<.05,{ }^{* *} p<.01$. See text for further details. 
Table 5: Estimating The Effects of WTO - Robustness Analysis

\begin{tabular}{|c|c|c|c|c|c|c|c|}
\hline & $\begin{array}{l}(1) \\
\text { Main }\end{array}$ & $\begin{array}{l}(2) \\
\text { OLS }\end{array}$ & $\begin{array}{c}(3) \\
\text { AsymFE }\end{array}$ & $\begin{array}{c}(4) \\
\text { GATT/WTO }\end{array}$ & $\begin{array}{c}(5) \\
\text { CtryVar }\end{array}$ & $\begin{array}{c}(6) \\
\text { GravVar }\end{array}$ & $\begin{array}{c}(7) \\
\text { DevStat }\end{array}$ \\
\hline One_GATTWTO & $\begin{array}{c}0.631 \\
(0.115)^{* *}\end{array}$ & $\begin{array}{c}0.220 \\
(0.150)\end{array}$ & $\begin{array}{c}0.631 \\
(0.107)^{* *}\end{array}$ & & $\begin{array}{c}0.642 \\
(0.133)^{* *}\end{array}$ & $\begin{array}{c}0.836 \\
(0.232)^{* *}\end{array}$ & \\
\hline Both_GATTWTO & $\begin{array}{c}0.366 \\
(0.082)^{* *}\end{array}$ & $\begin{array}{c}0.124 \\
(0.140)\end{array}$ & $\begin{array}{c}0.376 \\
(0.079)^{* *}\end{array}$ & & $\begin{array}{c}0.350 \\
(0.070)^{* *}\end{array}$ & $\begin{array}{c}1.007 \\
(0.160)^{* *}\end{array}$ & \\
\hline RTA & $\begin{array}{c}0.113 \\
(0.052)^{*}\end{array}$ & $\begin{array}{c}0.217 \\
(0.025)^{* *}\end{array}$ & $\begin{array}{c}0.116 \\
(0.051)^{*}\end{array}$ & $\begin{array}{c}0.116 \\
(0.053)^{*}\end{array}$ & $\begin{array}{c}0.066 \\
(0.047)\end{array}$ & $\begin{array}{c}0.428 \\
(0.080)^{* *}\end{array}$ & $\begin{array}{c}0.108 \\
(0.052)^{*}\end{array}$ \\
\hline One_GATT & & & & $\begin{array}{c}0.690 \\
(0.157)^{* *}\end{array}$ & & & \\
\hline One_WTO & & & & $\begin{array}{c}1.269 \\
(0.237)^{* *}\end{array}$ & & & \\
\hline Both_GATT & & & & $\begin{array}{c}0.531 \\
(0.113)^{* *}\end{array}$ & & & \\
\hline Both_WTO & & & & $\begin{array}{c}0.202 \\
(0.061)^{* *}\end{array}$ & & & \\
\hline polity2_BRDR & & & & & $\begin{array}{c}0.021 \\
(0.011)^{+}\end{array}$ & & \\
\hline $\mathrm{ln}_{-} \mathrm{GDP}_{-} \mathrm{BRDR}$ & & & & & $\begin{array}{c}0.116 \\
(0.086)\end{array}$ & & \\
\hline ln_Pop_BRDR & & & & & $\begin{array}{l}-0.078 \\
(0.352)\end{array}$ & & \\
\hline ln_DIST & & & & & & $\begin{array}{c}-0.613 \\
(0.062)^{* *}\end{array}$ & \\
\hline CNTG & & & & & & $\begin{array}{c}0.655 \\
(0.161)^{* *}\end{array}$ & \\
\hline LANG & & & & & & $\begin{array}{c}0.347 \\
(0.118)^{* *}\end{array}$ & \\
\hline CLNY & & & & & & $\begin{array}{c}0.162 \\
(0.097)^{+}\end{array}$ & \\
\hline One_GATTWTO_HH & & & & & & & $\begin{array}{l}0.346 \\
(0.305)\end{array}$ \\
\hline One_GATTWTO_HL & & & & & & & $\begin{array}{c}0.251 \\
(0.101)^{*}\end{array}$ \\
\hline One_GATTWTO_LL & & & & & & & $\begin{array}{c}0.742 \\
(0.127)^{* *}\end{array}$ \\
\hline Both_GATTWTO_HH & & & & & & & $\begin{array}{l}-0.075 \\
(0.074)\end{array}$ \\
\hline Both_GATTWTO_HL & & & & & & & $\begin{array}{c}0.346 \\
(0.091)^{* *}\end{array}$ \\
\hline Both_GATTWTO_LL & & & & & & & $\begin{array}{c}0.674 \\
(0.069)^{* *}\end{array}$ \\
\hline INTL_BRDR_1980 & $\begin{array}{c}-1.124 \\
(0.070)^{* *}\end{array}$ & $\begin{array}{c}-1.368 \\
(0.241)^{* *}\end{array}$ & $\begin{array}{c}-1.126 \\
(0.070)^{* *}\end{array}$ & $\begin{array}{c}-0.866 \\
(0.269)^{* *}\end{array}$ & $\begin{array}{c}-0.926 \\
(0.174)^{* *}\end{array}$ & $\begin{array}{c}-5.427 \\
(0.361)^{* *}\end{array}$ & $\begin{array}{c}-1.133 \\
(0.070)^{* *}\end{array}$ \\
\hline INTL_BRDR_1981 & $\begin{array}{c}-1.092 \\
(0.070)^{* *}\end{array}$ & $\begin{array}{c}-1.446 \\
(0.238)^{* *}\end{array}$ & $\begin{array}{c}-1.096 \\
(0.069)^{* *}\end{array}$ & $\begin{array}{c}-0.834 \\
(0.268)^{* *}\end{array}$ & $\begin{array}{c}-0.894 \\
(0.177)^{* *}\end{array}$ & $\begin{array}{c}-5.434 \\
(0.361)^{* *}\end{array}$ & $\begin{array}{c}-1.103 \\
(0.070)^{* *}\end{array}$ \\
\hline INTL_BRDR_1982 & $\begin{array}{c}-1.095 \\
(0.072)^{* *}\end{array}$ & $\begin{array}{c}-1.505 \\
(0.216)^{* *}\end{array}$ & $\begin{array}{c}-1.099 \\
(0.071)^{* *}\end{array}$ & $\begin{array}{c}-0.838 \\
(0.269)^{* *}\end{array}$ & $\begin{array}{c}-0.862 \\
(0.178)^{* *}\end{array}$ & $\begin{array}{c}-5.461 \\
(0.361)^{* *}\end{array}$ & $\begin{array}{c}-1.105 \\
(0.072)^{* *}\end{array}$ \\
\hline INTL_BRDR_1983 & $\begin{array}{c}-1.055 \\
(0.071)^{* *}\end{array}$ & $\begin{array}{c}-1.438 \\
(0.203)^{* *}\end{array}$ & $\begin{array}{c}-1.058 \\
(0.070)^{* *}\end{array}$ & $\begin{array}{c}-0.796 \\
(0.268)^{* *}\end{array}$ & $\begin{array}{c}-0.825 \\
(0.176)^{* *}\end{array}$ & $\begin{array}{l}-5.416 \\
(0.361)^{* *}\end{array}$ & $\begin{array}{c}-1.065 \\
(0.071)^{* *}\end{array}$ \\
\hline INTL_BRDR_1984 & -0.957 & -1.358 & -0.959 & -0.692 & -0.737 & -5.307 & -0.968 \\
\hline
\end{tabular}


Table 5 - Continued from previous page

\begin{tabular}{|c|c|c|c|c|c|c|c|}
\hline & $\begin{array}{c}(1) \\
\text { Main }\end{array}$ & $\begin{array}{c}(2) \\
\text { OLS }\end{array}$ & $\begin{array}{c}(3) \\
\text { AsymFE }\end{array}$ & $\begin{array}{c}(4) \\
\mathrm{GATT} / \mathrm{WTO}\end{array}$ & $\begin{array}{c}(5) \\
\text { CtryVar }\end{array}$ & $\begin{array}{c}(6) \\
\text { GravVar }\end{array}$ & $\begin{array}{c}(7) \\
\text { DevStat }\end{array}$ \\
\hline & $(0.074)^{* *}$ & $(0.204)^{* *}$ & $(0.073)^{* *}$ & $(0.268)^{*}$ & $(0.175)^{* *}$ & $(0.360)^{* *}$ & $(0.074)^{* *}$ \\
\hline \multirow[t]{2}{*}{ INTL_BRDR_1985 } & -0.936 & -1.381 & -0.937 & -0.670 & -0.705 & -5.299 & -0.945 \\
\hline & $(0.076)^{* *}$ & $(0.206)^{* *}$ & $(0.075)^{* *}$ & $(0.270)^{*}$ & $(0.174)^{* *}$ & $(0.363)^{* *}$ & $(0.076)^{* *}$ \\
\hline \multirow[t]{2}{*}{ INTL_BRDR_1986 } & -0.954 & -1.336 & -0.957 & -0.699 & -0.737 & -5.336 & -0.954 \\
\hline & $(0.071)^{* *}$ & $(0.200)^{* *}$ & $(0.071)^{* *}$ & $(0.270)^{* *}$ & $(0.158)^{* *}$ & $(0.367)^{* *}$ & $(0.071)^{* *}$ \\
\hline \multirow[t]{2}{*}{ INTL_BRDR_1987 } & -0.933 & -1.278 & -0.936 & -0.678 & -0.759 & -5.311 & -0.933 \\
\hline & $(0.071)^{* *}$ & $(0.199)^{* *}$ & $(0.070)^{* *}$ & $(0.271)^{*}$ & $(0.150)^{* *}$ & $(0.367)^{* *}$ & $(0.071)^{* *}$ \\
\hline \multirow[t]{2}{*}{ INTL_BRDR_1988 } & -0.844 & -1.230 & -0.846 & -0.588 & -0.688 & -5.220 & -0.844 \\
\hline & $(0.071)^{* *}$ & $(0.193)^{* *}$ & $(0.070)^{* *}$ & $(0.271)^{*}$ & $(0.141)^{* *}$ & $(0.366)^{* *}$ & $(0.071)^{* *}$ \\
\hline \multirow[t]{2}{*}{ INTL_BRDR_1989 } & -0.794 & -1.180 & -0.795 & -0.536 & -0.641 & -5.191 & -0.793 \\
\hline & $(0.075)^{* *}$ & $(0.191)^{* *}$ & $(0.074)^{* *}$ & $(0.272)^{*}$ & $(0.144)^{* *}$ & $(0.368)^{* *}$ & $(0.075)^{* *}$ \\
\hline \multirow[t]{2}{*}{ INTL_BRDR_1990 } & -0.653 & -1.121 & -0.655 & -0.398 & -0.539 & -5.059 & -0.653 \\
\hline & $(0.064)^{* *}$ & $(0.180)^{* *}$ & $(0.064)^{* *}$ & $(0.271)$ & $(0.125)^{* *}$ & $(0.367)^{* *}$ & $(0.064)^{* *}$ \\
\hline \multirow{2}{*}{ INTL_BRDR_1991 } & -0.653 & -1.027 & -0.654 & -0.397 & -0.557 & -5.044 & -0.652 \\
\hline & $(0.064)^{* *}$ & $(0.169)^{* *}$ & $(0.064)^{* *}$ & $(0.272)$ & $(0.122)^{* *}$ & $(0.368)^{* *}$ & $(0.064)^{* *}$ \\
\hline \multirow[t]{2}{*}{ INTL_BRDR_1992 } & -0.631 & -0.866 & -0.633 & -0.375 & -0.538 & -5.018 & -0.631 \\
\hline & $(0.061)^{* *}$ & $(0.160)^{* *}$ & $(0.060)^{* *}$ & $(0.272)$ & $(0.115)^{* *}$ & $(0.369)^{* *}$ & $(0.061)^{* *}$ \\
\hline \multirow[t]{2}{*}{ INTL_BRDR_1993 } & -0.587 & -0.834 & -0.589 & -0.329 & -0.492 & -4.965 & -0.585 \\
\hline & $(0.064)^{* *}$ & $(0.164)^{* *}$ & $(0.063)^{* *}$ & $(0.271)$ & $(0.116)^{* *}$ & $(0.368)^{* *}$ & $(0.064)^{* *}$ \\
\hline \multirow[t]{2}{*}{ INTL_BRDR_1994 } & -0.501 & -0.660 & -0.503 & -0.246 & -0.415 & -4.887 & -0.500 \\
\hline & $(0.065)^{* *}$ & $(0.146)^{* *}$ & $(0.064)^{* *}$ & $(0.272)$ & $(0.111)^{* *}$ & $(0.369)^{* *}$ & $(0.065)^{* *}$ \\
\hline \multirow[t]{2}{*}{ INTL_BRDR_1995 } & -0.479 & -0.515 & -0.481 & -0.494 & -0.408 & -4.875 & -0.478 \\
\hline & $(0.068)^{* *}$ & $(0.143)^{* *}$ & $(0.067)^{* *}$ & $(0.065)^{* *}$ & $(0.107)^{* *}$ & $(0.369)^{* *}$ & $(0.068)^{* *}$ \\
\hline \multirow[t]{2}{*}{ INTL_BRDR_1996 } & -0.459 & -0.486 & -0.461 & -0.473 & -0.389 & -4.868 & -0.457 \\
\hline & $(0.067)^{* *}$ & $(0.137)^{* *}$ & $(0.066)^{* *}$ & $(0.064)^{* *}$ & $(0.105)^{* *}$ & $(0.369)^{* *}$ & $(0.067)^{* *}$ \\
\hline \multirow[t]{2}{*}{ INTL_BRDR_1997 } & -0.341 & -0.336 & -0.343 & -0.356 & -0.269 & -4.754 & -0.340 \\
\hline & $(0.064)^{* *}$ & $(0.151)^{*}$ & $(0.063)^{* *}$ & $(0.060)^{* *}$ & $(0.101)^{* *}$ & $(0.369)^{* *}$ & $(0.064)^{* *}$ \\
\hline \multirow[t]{2}{*}{ INTL_BRDR_1998 } & -0.273 & -0.333 & -0.275 & -0.288 & -0.201 & -4.707 & -0.272 \\
\hline & $(0.060)^{* *}$ & $(0.139)^{*}$ & $(0.058)^{* *}$ & $(0.056)^{*}$ & $(0.095)^{*}$ & $(0.370)^{* *}$ & $(0.059)^{* *}$ \\
\hline \multirow[t]{2}{*}{ INTL_BRDR_1999 } & -0.278 & -0.328 & -0.280 & -0.292 & -0.209 & -4.707 & -0.277 \\
\hline & $(0.062)^{* *}$ & $(0.133)^{*}$ & $(0.061)^{* *}$ & $(0.058)^{* *}$ & $(0.094)^{*}$ & $(0.368)^{* *}$ & $(0.062)^{* *}$ \\
\hline \multirow[t]{2}{*}{ INTL_BRDR_2000 } & -0.117 & -0.183 & -0.119 & -0.133 & -0.052 & -4.531 & -0.117 \\
\hline & $(0.062)^{+}$ & $(0.131)$ & $(0.061)^{+}$ & $(0.058)^{*}$ & $(0.090)$ & $(0.368)^{* *}$ & $(0.062)^{+}$ \\
\hline \multirow[t]{2}{*}{ INTL_BRDR_2001 } & -0.138 & -0.117 & -0.140 & -0.141 & -0.068 & -4.607 & -0.138 \\
\hline & $(0.051)^{* *}$ & $(0.130)$ & $(0.051)^{* *}$ & $(0.051)^{* *}$ & $(0.085)$ & $(0.366)^{* *}$ & $(0.051)^{* *}$ \\
\hline \multirow[t]{2}{*}{ INTL_BRDR_2002 } & -0.129 & -0.110 & -0.132 & -0.132 & -0.064 & -4.617 & -0.129 \\
\hline & $(0.055)^{*}$ & $(0.127)$ & $(0.055)^{*}$ & $(0.055)^{*}$ & $(0.083)$ & $(0.367)^{* *}$ & $(0.055)^{*}$ \\
\hline \multirow[t]{2}{*}{ INTL_BRDR_2003 } & -0.158 & -0.098 & -0.160 & -0.160 & -0.109 & -4.661 & -0.158 \\
\hline & $(0.060)^{* *}$ & $(0.125)$ & $(0.059)^{* *}$ & $(0.060)^{* *}$ & $(0.081)$ & $(0.368)^{* *}$ & $(0.060)^{* *}$ \\
\hline \multirow[t]{2}{*}{ INTL_BRDR_2004 } & -0.097 & -0.084 & -0.100 & -0.100 & -0.061 & -4.620 & -0.097 \\
\hline & $(0.056)^{+}$ & $(0.123)$ & $(0.055)^{+}$ & $(0.055)^{+}$ & $(0.073)$ & $(0.368)^{* *}$ & $(0.056)^{+}$ \\
\hline INTL BRDR 2005 & -0.066 & -0.043 & -0.068 & -0.069 & -0.037 & -4.612 & -0.066 \\
\hline & $(0.053)$ & $(0.116)$ & $(0.052)$ & $(0.052)$ & $(0.068)$ & $(0.369)^{* *}$ & $(0.053)$ \\
\hline INTL BRDR 2006 & 0.002 & -0.067 & -0.000 & -.0000 & 0.024 & -4.559 & 0.002 \\
\hline & $(0.050)$ & $(0.113)$ & $(0.049)$ & $(0.049)$ & $(0.064)$ & $(0.369)^{* *}$ & $(0.050)$ \\
\hline INTL BRDR 2007 & -0.006 & -0.092 & -0.007 & -0.006 & 0.004 & -4.583 & -0.005 \\
\hline & $(0.053)$ & $(0.114)$ & $(0.052)$ & $(0.052)$ & $(0.066)$ & $(0.370)^{* *}$ & $(0.053)$ \\
\hline INTL_BRDR_2008 & 0.023 & 0.003 & 0.022 & 0.022 & 0.024 & -4.573 & 0.023 \\
\hline & $(0.044)$ & $(0.116)$ & $(0.044)$ & $(0.044)$ & $(0.057)$ & $(0.367)^{* *}$ & $(0.044)$ \\
\hline INTL_BRDR_2009 & -0.052 & -0.083 & -0.052 & -0.052 & -0.042 & -4.674 & -0.052 \\
\hline
\end{tabular}


Table 5 - Continued from previous page

\begin{tabular}{|c|c|c|c|c|c|c|c|}
\hline & $\begin{array}{c}(1) \\
\text { Main }\end{array}$ & $\begin{array}{l}(2) \\
\text { OLS }\end{array}$ & $\begin{array}{c}(3) \\
\text { AsymFE }\end{array}$ & $\begin{array}{c}(4) \\
\text { GATT/WTO }\end{array}$ & $\begin{array}{c}(5) \\
\text { CtryVar }\end{array}$ & $\begin{array}{c}(6) \\
\text { GravVar }\end{array}$ & $\begin{array}{c}(7) \\
\text { DevStat }\end{array}$ \\
\hline & $(0.037)$ & $(0.113)$ & $(0.036)$ & $(0.036)$ & $(0.045)$ & $(0.365)^{* *}$ & $(0.037)$ \\
\hline INTL_BRDR_2010 & 0.022 & -0.003 & 0.021 & 0.022 & 0.023 & -4.627 & 0.022 \\
\hline INTL_BRDR_2011 & $\begin{array}{c}(0.035) \\
0.060 \\
(0.032)^{+}\end{array}$ & $\begin{array}{c}(0.114) \\
0.113 \\
(0.094)\end{array}$ & $\begin{array}{c}(0.034) \\
0.060 \\
(0.031)^{+}\end{array}$ & $\begin{array}{c}(0.034) \\
0.060 \\
(0.031)^{+}\end{array}$ & $\begin{array}{c}(0.042) \\
0.050 \\
(0.041)\end{array}$ & $\begin{array}{c}(0.366)^{* *} \\
-4.599 \\
(0.366)^{* *}\end{array}$ & $\begin{array}{c}(0.034) \\
0.060 \\
(0.031)^{+}\end{array}$ \\
\hline INTL_BRDR_2012 & $\begin{array}{c}0.051 \\
(0.025)^{*}\end{array}$ & $\begin{array}{c}0.104 \\
(0.094)\end{array}$ & $\begin{array}{c}0.050 \\
(0.024)^{*}\end{array}$ & $\begin{array}{c}0.050 \\
(0.025)^{*}\end{array}$ & $\begin{array}{c}0.040 \\
(0.032)\end{array}$ & $\begin{array}{c}-4.614 \\
(0.367)^{* *}\end{array}$ & $\begin{array}{c}0.051 \\
(0.025)^{*}\end{array}$ \\
\hline INTL_BRDR_2013 & $\begin{array}{c}0.068 \\
(0.024)^{* *}\end{array}$ & $\begin{array}{c}0.118 \\
(0.088)\end{array}$ & $\begin{array}{c}0.068 \\
(0.024)^{* *}\end{array}$ & $\begin{array}{c}0.068 \\
(0.024)^{* *}\end{array}$ & $\begin{array}{c}0.053 \\
(0.031)^{+}\end{array}$ & $\begin{array}{c}-4.604 \\
(0.366)^{* *}\end{array}$ & $\begin{array}{c}0.068 \\
(0.024)^{* *}\end{array}$ \\
\hline INTL_BRDR_2014 & $\begin{array}{c}0.073 \\
(0.020)^{* *}\end{array}$ & $\begin{array}{c}0.125 \\
(0.088)\end{array}$ & $\begin{array}{c}0.074 \\
(0.020)^{* *}\end{array}$ & $\begin{array}{c}0.074 \\
(0.020)^{* *}\end{array}$ & $\begin{array}{c}0.057 \\
(0.026)^{*}\end{array}$ & $\begin{array}{c}-4.599 \\
(0.365)^{* *}\end{array}$ & $\begin{array}{c}0.073 \\
(0.020)^{* *}\end{array}$ \\
\hline $\begin{array}{l}\text { INTL_BRDR_2015 } \\
\text { INTL_BRDR_2016 }\end{array}$ & $\begin{array}{c}0.098 \\
(0.015)^{* *}\end{array}$ & $\begin{array}{c}0.071 \\
(0.076)\end{array}$ & $\begin{array}{c}0.099 \\
(0.015)^{* *}\end{array}$ & $\begin{array}{c}0.099 \\
(0.015)^{* *}\end{array}$ & $\begin{array}{c}0.088 \\
(0.017)^{* *}\end{array}$ & $\begin{array}{c}-4.595 \\
(0.365)^{* *} \\
-4.722 \\
(0.367)^{* *}\end{array}$ & $\begin{array}{c}0.098 \\
(0.015)^{* *}\end{array}$ \\
\hline Country pairs & 6347 & 6347 & 6347 & 6347 & 6167 & 6347 & 6347 \\
\hline Countries & 178 & 178 & 178 & 178 & 131 & 178 & 178 \\
\hline Estimator & PPML & OLS & PPML & PPML & PPML & PPML & PPML \\
\hline Imp-time Exp-time FEs & Yes & Yes & Yes & Yes & Yes & Yes & Yes \\
\hline Symmetric pair FEs & Yes & Yes & No & Yes & Yes & No & Yes \\
\hline Asymmetric pair FEs & No & No & Yes & No & No & No & No \\
\hline
\end{tabular}

Notes: This table is the complete version of Table 2 from the main text. The table reports robustness results from econometric models that study the impact of WTO on international trade. The dependent variable is bilateral trade in levels in all columns besides column (2), where the dependent variable is the log of bilateral trade flows. All estimates are obtained in panel settings with the PPML estimator besides column (2), where we use OLS, exporter-time and importer-time fixed effects, time-varying border variables, as well as symmetric (asymmetric in column (3)) country-pair fixed effects. For presentation purposes, we omit the estimates of all fixed effects, including the constant. Standard errors are clustered by country pair and are reported in parentheses. ${ }^{+} p<0.10$, ${ }^{*} p<.05,{ }^{* *} p<.01$. See text for further details. 